\title{
Devir da fábrica: patrimônio industrial em disputa na zona leste de São Paulo
}

The become of the factory: Industrial Heritage at strife in the East Zone of São Paulo

hitps://doi.org/10.1590/1982-02672020v28e17

\section{CLARISSA MARIA GAGLIARDI'}

https:/ / orcid.org/0000-0001-795 1-0748

Universidade de São Paulo / São Paulo, SP, Brasil

\section{MÔNICA DE CARVALHO²}

http:/ / orcid.org/0000-0003-2391-6735

Pontifícia Universidade Católica de São Paulo / São Paulo, SP, Brasil

RESUMO: Os processos de reconversão econômica observados nas metrópoles mundiais desde a última década do século passado têm sido frequentemente analisados tendo por referência o campo da ciência econômica, cuja ênfase recai sobre as consequências da desindustrialização, permanecendo com menor problematização os destinos do ambiente construído objetivado no espaço urbano durante a atividade industrial. Em São Paulo, vive-se um crescente processo de desconcentração industrial desde o início deste milênio, sendo a zona leste a que tem sofrido seu maior impacto. Tendo disponibilizado metragens significativas, instalou-se uma disputa em torno da requalificação desse patrimônio industrial, opondo de um lado capital imobiliário e de outro, nem sempre associados, moradores e edilidade pública, representada sobretudo nos órgãos de preservação. Abre-se, portanto, a partir desse conflito instalado, a possibilidade de propor uma análise do processo de reconversão econômica a partir da perspectiva orientada pelo campo de conhecimento do patrimônio

\begin{abstract}
1. Graduada e mestre em Turismo pelo Centro Universitário Ibero-Americano; mestre e doutora em Sociologia pela Pontifícia Universidade Católica de São Paulo (PUC-SP) e Master em Gestão e Valorização de Centros Históricos pela Università La Sapienza di Roma. Atualmente é professora do Departamento de Relações Públicas, Propaganda e Turismo da Escola de Comunicação e Artes da Universidade de São Paulo (USP) e do Programa de Pós-Graduação Interunidades em Museologia (PPGMus) da USP. E-mail: <clarissamrg@usp. br>

2. Graduada e mestre em Ciências Sociais pela USP, doutora em Ciências Sociais pela PUC-SP. É pesquisadora do Observatório das Metrópoles-SP, vinculado a Universidade Federal do Rio de Janeiro, e do Núcleo de Pesquisas Urbanas do Programa de Pós-Graduação em Ciências Sociais da PUC-SP. E-mail: <monicacarvalho@ uol.com.br $>$
\end{abstract}


cultural. Considerando as diretrizes internacionais para a preservação do patrimônio cultural, incluindo-se aí o papel social requerido dos museus, e do caráter multidimensional das experiências que se tornaram paradigmáticas da salvaguarda do patrimônio industrial, se evidencia o fato de que o simples tombamento e/ou manutenção física de imóveis fabris não são ações suficientes para que se cumpra a função social do patrimônio, inclusive da perspectiva do próprio trabalho como cultura viva e processo formador de identidades. É nesse sentido que, a partir da análise de antigas fábricas refuncionalizadas na zona leste de São Paulo, o texto busca problematizar as destinações de uso dos imóveis fabris.

PALAVRAS-CHAVE: Patrimônio industrial. Reconversão econômica. Zona leste de São Paulo.

ABSTRACT: The processes of economic reconversion that took place in the world metropolises since the last decade of the last century have been frequently analyzed with reference to the field of economic science, whose emphasis is on the consequences of deindustrialization, giving less enhancement to the destinies of the built environment in the urban space during industrial activity. In São Paulo there has been a growing process of industrial deconcentration since the beginning of this millennium, in which the East Zone has suffered its greatest impact. Since there are significant areas involved, a dispute arose over the requalification of this industrial heritage, opposing on one side real estate business and on the other, not always associated, residents and the city council, mainly represented by the preservation departments. From this installed conflict arises the possibility of proposing an analysis of the process of economic conversion from the perspective guided by the field of knowledge of cultural heritage. Considering the international guidelines for the preservation of cultural heritage, including the required social role of museums, and the multidimensional character of experiences that have become paradigmatic for the safeguarding of industrial heritage, it is evident that the act of putting under governmental trust and / or simple maintenance of factory buildings are not enough actions to fulfill the social function of heritage, including from the perspective of work itself as a living culture and identity-forming process. Based on the analysis of the new functions given to old factories in the East Zone of São Paulo, the text seeks to ponder over the intended use of factory buildings.

KEYWORDS: Industrial heritage. Economic reconversion. East Zone of São Paulo. 
processo de reconversão econômica das metrópoles mundiais tem sido objeto dos mais diferentes campos de conhecimento, cujas abordagens comungam a problematização das consequências materiais dele decorrentes, desde as transformações daí advindas para o mercado de trabalho, com a perda significativa dos empregos na atividade industrial e sua substituição pelos empregos precarizados do setor terciário, até a mudança na paisagem urbana, com a substituição dos galpões industriais pelos edifícios monumentais da economia globalizada.

Tomando por referência o campo do patrimônio histórico e a luta das classificações ${ }^{3}$ nele empreendida em torno dos bens a serem preservados, sejam eles materiais, sejam imateriais, o objetivo deste artigo é sugerir que as transformações identificadas no mundo da produção introduzem ao mesmo tempo uma disputa no campo simbólico, pois, nesse caso, o que está em jogo, para além da mera substituição de uma atividade produtiva por outra, de um tipo de mobiliário urbano por outro, é o conflito em torno de uma representação de mundo, opondo a sociedade organizada em torno da produção - o trabalho industrial sendo a sua forma objetivada - à sociedade rentista do capital urbano, ${ }^{4}$ própria às formas contemporâneas de produção do espaço urbano.

Tal perspectiva ganha destaque, se concordarmos com Marins, que desde os anos 1930 as ações preservacionistas do Estado, sobretudo do governo federal, sempre estiveram associadas à defesa de certa visão de mundo. Naquele momento, o ethos nacional priorizava, nas suas escolhas, bens materiais que contribuíssem para a construção da própria ideia de nação. ${ }^{5}$ Mesmo que mais recentemente o conteúdo definidor desse ethos tenha se alterado, ${ }^{\circ}$ com a inserção de outros bens, inclusive imateriais, decorrentes da produção cultural de grupos até então excluídos da cultura reconhecidamente hegemônica, as ações de patrimonialização mantêm o poder simbólico ${ }^{7}$ de legitimar valores sociais consubstanciados nos bens preservados.

No entanto, por maior que tenha sido a ampliação do leque na classificação dos bens memoráveis, permanecem fora do escopo "bairros operários, bairrosjardins, bairros de palacetes, áreas intensamente verticalizadas ou marcadas pela paisagem industrial"8 (grifo nosso). Ou seja, apesar da reconversão econômica estar em franco processo no país desde o início do milênio, sobretudo nas metrópoles de perfil industrial como São Paulo, ações preservacionistas protetivas do Estado emergem apenas como reação ao desaparecimento iminente dos galpões industriais.

Muito diferentemente é o que tem sido observado nas experiências estrangeiras ou mesmo aquelas propostas em convenções internacionais que
4. Segundo Marques (2016), o capital urbano é aquele "que têm seus processos de acumulação e lucratividade oriundos diretamente da produção da cidade" ( $\mathrm{p}$. 17), como são, por exemplo, as incorporadoras e as empresas de construção civil, não só nacionais.

5. Marins (2016, p. 11).

6. Ibid., p. 12.

7. Para uma discussão sobre poder simbólico, cf. Bourdieu (2009, p. 7-16).

8. Marins (2016, p. 16). É bem verdade que essa é uma afirmação marginal no texto de Marins, quando na construção de contraponto ao que tem sido a marca preservacionista do Iphan. No entanto, parece sintomático que, em seu exemplo, ocupe centralidade a paisagem que se produziu quando da sociedade industrial. 
9. The desindustrialization of America é título de estudo publicado nos anos de 1970, de autoria de Bluestone e Harrison, conforme citado por Hall (2011, p. 408).

10. Tregenna (2009) apud Oreiro; Feijó (2010, p. 221). Para uma discussão do processo de desindustrialização no Brasil, cf. Cano (2012) e Monteiro; Lima (2017). Relatório da Fiesp (2017) também aponta para o mesmo processo em todo o país, confirmado recentemente pelos dados de produção industrial mensal (PIM) apresentados pelo Instituto Brasileiro de Geografia e Estatística (IBGE, PIM-dez. 2019).

11. Cf. Sassen (1998). apontam para uma ideia de preservação extensiva aos processos sociais vinculados à produção industrial, abrangendo matrizes de recursos energéticos, redes de transporte e sítios, estruturas, equipamentos e paisagens, matériasprimas e documentos, sem contar a preservação de conjunto representativo da diversidade de memórias decorrentes das muitas identidades profissionais forjadas ao longo dos processos de produção e organização do trabalho fabril.

Para compreender o significado relevante dessas iniciativas internacionais, queremos sugerir que não estamos diante somente de uma maior disposição em preservar a memória industrial. Trata-se, antes, de um posicionamento em favor de uma concepção de mundo que se configurou em torno da atividade industrial e que está em deperecimento há mais tempo nas cidades europeias e americanas. Queremos, portanto, sugerir que a ação preservacionista caminha ao lado da compreensão do significado simbólico do processo de reconversão econômica.

Entendida como a substituição das atividades industriais pelos serviços da economia globalizada na configuração da centralidade produtiva das metrópoles, a reconversão econômica foi originalmente identificada por meio da desconcentração industrial observada nas cidades tradicionalmente industriais do Reino Unido e dos EUA. Naquele momento, década de 1970, o "efeito combinado de indústrias em fuga, fechamento de fábricas e permanentes reduções físicas", com a perda consequente de "38 milhões de empregos" só no cinturão fabril americano, ganharia ares de tendência, batizada como desindustrialização. ${ }^{9}$

Embora associadas, a desindustrialização não se confunde com a desconcentração industrial, se considerarmos a discussão no campo econômico. No primeiro caso, assumidos critérios estabelecidos por Tregenna, ${ }^{10}$ trata-se de constatar a incapacidade que as indústrias de transformação possuem de gerar empregos e contribuir de forma significativa para o aumento do Produto Interno Bruto (PIB). Da perspectiva do território urbano, no entanto, interessa a questão da desconcentração industrial, mais diretamente vinculada à migração das plantas industriais para municípios vizinhos ou mesmo internacionais. Pois, nesse caso, a cidade sofre tanto em termos fiscais como no destino a ser conferido ao ambiente construído deixado para trás, muitas vezes metragens significativas de área urbana valorizada por séculos de investimento em infraestrutura.

Essa questão não passou despercebida pelos especialistas em estudos urbanos. Foi na década de 1990 que Saskia Sassen, ${ }^{11}$ em obra que se tornaria clássica, chamou a atenção para esse aspecto quando notou que a desconcentração industrial não produziria cidades fantasma. Ao contrário, mobilizaria ações no sentido de atrair capitais, agora voláteis em função da intensificação dos fluxos financeiros globais, destinados ao investimento no setor terciário, sobretudo aquele talhado para atender 
às demandas de uma economia globalizada. $\bigcirc$ epíteto "cidade global" para as antigas "cidades fabris" ganhou terreno e passou a orientar um conjunto de estudos interessados na sua caracterização. No Brasil, a discussão bifurcou-se entre aqueles que se dedicaram a pensar criticamente o planejamento urbano voltado à atração de capitais - o chamado planejamento estratégico ${ }^{12}$ - e aqueles que denunciavam a preocupação em ranquear as cidades visando alcançar o novo qualificativo. ${ }^{13}$

Sem que tenhamos espaço para avançar nesse debate, importa aqui introduzir um elemento que dialoga diretamente com o campo do patrimônio histórico. Foi Harvey ${ }^{14}$ quem chamou a atenção para o fato de que, ainda que a reconversão econômica seja tendência, há que se pensar o que fazer com o ambiente construído abandonado pela migração das plantas industriais. Dito de outra forma: entre a "cidade fabril" e a "cidade global" há um hiato que demanda a atenção daqueles que se preocupam com o destino das cidades sobre as quais durante séculos recaíram investimentos em infraestrutura urbana, contribuindo para a valorização exponencial de suas terras. Sobretudo, recentemente, quando ficou demonstrado que mais do que investir em serviços da economia globalizada, o que ainda produziria um retorno para a cidade que acolhe $o$ investimento, o capital urbano tem interesse na produção do ambiente construído antes como ativo financeiro. ${ }^{15}$ Nesse caso, a cidade como produto histórico da ação de seus moradores destinado à sua apropriação se reduz ao espaço físico designado à reprodução do capital especulativo desterritorializado. A cidade global, nesse caso, assume-se não só como nó da economia globalizada, como indicava a discussão de Sassen, mas também projeta-se em outra escala, vista de longe e do alto, como espaço rentável disponível como matéria-prima para a produção de ativo imobiliário.

Tendo esse cenário por pano de fundo entendemos que o campo do patrimônio histórico pode se constituir como ator relevante na disputa pelo ambiente construido abandonado pela atividade industrial, assumindo posicionamento que não se restringe à preservação do bem material em si, como a constituir monumentos fadados à glorificação de um passado nem tão glorioso assim, mas garantindo-the função social que não seja aquela destinada à especulação rentista, própria aos investimentos do capital urbano globalizado.

É para propor essa discussão que nos voltamos para a cidade de São Paulo, mais especificamente para a zona leste da cidade, tradicional berço da indústria paulista, e que desde o início dos anos 2000 tem sofrido o processo de desindustrialização e a desconcentração industrial. ${ }^{16}$ Trata-se de apresentar a situação de disputa em torno dos galpões fabris, bem como a ação até o momento empreendida pelos setores de preservação patrimonial.
12. Cf. Arantes; Vainer; Maricato (2000); Frugoli Jr. (2000); Carlos (2001).

13. Cf. Carvalho (2000); Ferreira (2007).

14. Harvey (2005, p. 161188).

15. Cf. Fix (2007); Rolnik (2015); Sassen (2016).

16. Cf. Carvalho et al. (2018). 
17. Castriota (2009, p. 155).

18. Parent (1988, p. 32).
Além dessa introdução e as considerações finais, este artigo retoma algumas das principais iniciativas internacionais de preservação do patrimônio industrial, avançando para o estudo de caso da cidade de São Paulo, para concluir sobre a importância de que essa discussão seja apropriada pelo campo do patrimônio histórico agora que a reconversão econômica alcançou o território brasileiro.

\section{DIRETRIZES INTERNACIONAIS E AS MÚLTIPLAS DIMENSÕES DO PATRIMÔNIO CULTURAL}

As Cartas Patrimoniais oferecem um panorama importante das evoluções conceituais, normas e condutas de proteção dos bens patrimoniais. Analisando as preocupações expressas nesses documentos, percebe-se que, no início, os bens eleitos para serem preservados eram majoritariamente edificações e artefatos individuais, selecionados no campo da arquitetura por critérios de excepcionalidade, valor histórico ou estético, que deveriam ter sua integridade preservada diante do desenvolvimento urbano. Em termos culturais, tratava-se de produtos da cultura erudita, derivados, em geral, de segmentos sociais dominantes. ${ }^{17}$ Paulatinamente, porém, verificou-se uma ampliação no espaço, no tempo e no caráter tipológico dos bens a serem protegidos.

Das Cartas de Atenas, produzidas em 1931 pelo Escritório Internacional dos Museus, trazendo deliberações a respeito da conservação do patrimônio de caráter monumental e, em 1933, a partir do Congresso Internacional de Arquitetura Moderna (Ciam), influenciando o planejamento urbano em todo o mundo por meio da difusão dos conceitos modernistas, os documentos têm evidenciado desafios cada vez maiores na preservação do patrimônio cultural e natural.

Produto da Conferência Geral das Nações Unidas para a Educação, a Ciência e a Cultura, em 1972, a Convenção para a Proteção do Patrimônio Cultural e Natural ou Recomendação de Paris confirma a ampliação da dimensão territorial que o conceito de patrimônio cultural adquirirá nos anos sucessivos, ao propor diferentes categorias de bens a serem preservados, dos monumentos, passando pelos conjuntos e chegando aos sítios, além de definir princípios comuns para a proteção nacional e internacional do patrimônio cultural e natural. A institucionalização do patrimônio da humanidade, nessa ocasião, dilata ainda mais o conceito, ao admitir a necessidade de uma "atualização da noção de patrimônio em um mundo em que, sob o impacto do desenvolvimento científico e da ampliação dos conceitos de história e cultura, tudo o que existe tende a integrar-se ao patrimônio humano". ${ }^{18}$ 
Outro documento importante pelas diretrizes que estabelece mundialmente é a Carta Europeia do Patrimônio, também chamada de Carta ou Manifesto de Amsterdã, apresentada pelo lcomos em 1975. O documento aponta para um tipo de conduta para a preservação de áreas históricas que ficou conhecida como "conservação integrada". Segundo Silvio Mendes Zancheti, esta carta sugere "uma abordagem de integração do planejamento da cidade contemporânea e de áreas urbanas patrimoniais para sua utilização, segundo novos usos e necessidade sociais". ${ }^{19}$ Dessa forma, o documento condiciona o alcance de seus objetivos a uma integração entre as políticas de patrimônio e planejamento urbano. ${ }^{20}$ É a partir dessa perspectiva que a preservação de edificações fabris, muitas vezes localizadas em áreas de interesse do mercado imobiliário, passa a ser objeto de atenção, sugerindo a articulação entre os planos diretores e os órgãos patrimoniais, de maneira a evitar que o crescimento urbano contribua para seu desaparecimento.

A partir dos anos 2000, a Unesco inicia um amplo programa para lidar com o patrimônio imaterial, aprovando, em 2003, a Convenção para a Salvaguarda do Patrimônio Cultural Intangível, definindo-o por

[...] práticas, representações, expressões, conhecimentos e técnicas - junto com os instrumentos, objetos, artefatos e lugares culturais que the são associados - que as comunidades, os grupos e, em alguns casos, os indivíduos reconhecem como parte integrante do seu patrimônio cultural. ${ }^{21}$

A sofisticação do pensamento trazido por essa convenção se expressa na oposição à prática usual, no âmbito da preservação de bens culturais, pois "mais do que lidar com coleções de objetos e lembranças congeladas no tempo, importa aqui considerar os processos sociais a eles associados, bem como as condições de sua produção". ${ }^{22}$

Reforça a aproximação entre as dimensões materiais e imateriais do patrimônio a sua confluência na Carta de Nizhny Tagil para o Patrimônio Industrial, aprovada na Conferência do International Committee for the Conservation of the Industrial Heritage (Comissão Internacional para a Conservação do Patrimônio Industrial) realizada na Rússia em 2003,23 para quem "o patrimônio industrial revestese de um valor social como parte do registro de vida de homens e mulheres comuns e, como tal, proporciona-thes um importante sentimento de identidade", devendo-se considerar, inclusive, sua inerência "aos registros intangíveis contidos na memória dos homens e nas suas tradições". A definição de patrimônio industrial adotada no documento reforça um entendimento mais amplo desse patrimônio, compreendendo
19. Zanchetti (2011, p. 3).

20. Estes princípios não ficaram restritos à Europa. Em 1976, a Declaração de Nairóbi incorpora muitos aspectos que pressupunham a integração entre conservação de conjuntos históricos e política urbana. Castriota (2009, p. 232).

21. Convenção para a Salvaguarda do Patrimônio Cultural Intangível, 2003.

22. Arantes (2009, p. 176).

23. A primeira conferência internacional para a Conservação do Patrimônio Industrial foi realizada na Grã-Bretanha, em 1973, na cidade de Ironbridge e, em sua terceira edição, em Gangarde, na Suécia, foi criado o Ticcih - The International Committee for the Conservation of the Industrial Heritage. 
24. Carta de Nizhny Tagil para o Patrimônio Industrial, 2003

25. Princípios conjuntos do Icomos - Ticcih para a Conservação de Sítios, Estruturas, Áreas e Paisagens de Patrimônio Industrial, aprovados na $17^{\circ}$ Assembleia Geral do ICOMOS, também chamados Princípios de Dublin.
[...] os vestígios da cultura industrial que possuem valor histórico, tecnológico, social, arquitetônico ou científico. Estes vestígios englobam edifícios e maquinaria, oficinas, fábricas, minas e locais de tratamento e de refino, entrepostos e armazéns, centros de produção, transmissão e utilização de energia, meios de transporte e todas as suas estruturas e infraestruturas, assim como os locais onde se desenvolveram atividades sociais relacionadas com a indústria, tais como habitações, locais de culto ou de educação. ${ }^{24}$

Diante das diretrizes internacionais para a preservação do patrimônio cultural e do caráter multidimensional das experiências que se tornaram paradigmáticas da salvaguarda do patrimônio industrial, se evidencia o fato de que o simples tombamento e/ou manutenção física de imóveis fabris não são ações suficientes para que se cumpra a função social do patrimônio, inclusive da perspectiva do próprio trabalho como processo formador de identidades, entendido como um patrimônio a ser salvaguardado e mantido como cultura viva na sociedade.

A natureza então singular deste patrimônio mobiliza lcomos e Ticcih, em 2011 , para a elaboração de princípios que visem a auxiliar ações de "conhecimento, proteção, conservação e valorização do patrimônio industrial", destacando "saber-fazer técnicos, a organização do trabalho e dos trabalhadores, ou um complexo legado de práticas sociais e culturais resultantes da influência da indústria na vida das comunidades", ${ }^{25}$ incluindo claramente a dimensão imaterial na constituição do patrimônio industrial. Os Princípios de Dublin consideram, assim, a amplitude e a complexidade desta tipologia de patrimônio em termos de suas conexões com os meios natural e sociocultural, processos, territórios e paisagens para referenciar diretrizes para sua preservação, não sem deixar um rastro de indagações a respeito do que representam. Embora os debates em torno do patrimônio cultural e da museologia tenham alguns contornos específicos, ambos consideram a salvaguarda do patrimônio industrial pelo interesse que a representação do bem suscita. A evolução conceitual e prática verificada nas últimas décadas nessas duas áreas conflui para o tema da proteção dos suportes culturais intangíveis, permitindo então enquadrar a discussão em tela no sentido da salvaguarda do trabalho - e não apenas dos vestígios materiais da fábrica -, seja em ações de patrimonialização, seja de musealização.

Em perspectiva antropológica, a formação do patrimônio cultural imaterial caminhou ao lado das mudanças que a noção de patrimônio etnológico trouxe ao campo museal, implicando outras referências para procedimentos de conservação, documentação, pesquisa e comunicação. Nesse contexto, o legado industrial pode ser visto como objeto museal, mas não como aquele que se retira do circuito da vida, mas sim que se interpreta a partir de um território vivo e em constante ressignificação. Como sugere Dominique Poulot, fazendo referência a 
Hugues de Varine-Bohan, as populações passam a assumir menos um papel de consumidor do museu e mais de ator, "para não dizer de autor". ${ }^{26}$

Por fim, é importante ainda levar em conta as prerrogativas da Mesa de Santiago, encontro internacional do Icom que, em 1972, reuniu profissionais da área de museus para um exercício de questionamento da museologia e do papel dos museus no desenvolvimento social, originando um amplo movimento de museus engajados e mais integrados à vida da sociedade, de um fazer museal mais participativo. Tentava-se superar, assim, uma concepção de cultura pautada pela produção e circulação de bens culturais de uma elite, ampliando-se a compreensão do museu como promotor de mudanças apoiadas nas demandas sociais.

Às tendências de conceituar o patrimônio a partir de uma matriz cada vez mais complexa e com foco mais nos processos sociais do que apenas em seus suportes materiais, soma-se também a busca por um papel mais ativo do patrimônio no desenvolvimento das sociedades, incluindo-se aí os museus, tanto aqueles de origem clássica, tradicionais, quanto os mais experimentais, comunitários e tributários da Nova Museologia, movimento que enfatizou a vocação social e a interdisciplinaridade do museu ${ }^{27}$

Diante destas concepções, portanto, "a indelével associação entre os espaços de trabalho e as memórias dos trabalhadores incide também na dimensão imaterial da experiência industrial los saberes, as rotinas de trabalho, as práticas cotidianas)", ${ }^{28}$ sendo válido analisar em que medida os processos de requalificação têm contemplado tais dimensões desse patrimônio.

\section{REFERÊNCIAS EUROPEIAS DE PRESERVAÇÃO E RESSIGNIFICAÇÃO DO PATRIMÔNIO INDUSTRIAL NO CONTEXTO CONTEMPORÂNEO}

Em diferentes partes do mundo, o reconhecimento da importância da preservação dos vestígios materiais da industrialização - dos edifícios, processos e ferramentas às paisagens em que se inscrevem -, caminhou pari passu ao processo de desindustrialização e consequente obsolescência das estruturas que the deram suporte, gerando disputas patrimoniais e fortes discussões a respeito das demolições e descaracterizações oriundas de processos de reconversão desses imóveis no contexto urbano.

Caso emblemático na Alemanha, a região do Ruhr viveu o enfrentamento de conflitos gerados pela reutilização de edificações industriais e de seus
26. Poulot (2013, p. 56).

27. Para outras referências sobre este conceito, cf. Desvallées; Mairesse (2013).

28. Meneguello (2011, p. 1819). 
29. Cf. Marchi (2005).

30. Cf. Berger; Wicke (2014).

31. Cf. DW Brasil (2019).

32. Cf. Berger; Wicke (2014) terrenos após processo de desindustrialização. A ocupação do território a partir da segunda metade do século XIX esteve totalmente relacionada à atividade industrial. Por mais de cem anos, carvão e aço ditaram a economia e a vida urbana da região. ${ }^{29} \mathrm{Com} \circ$ abandono das atividades mineradoras e da indústria em geral, Ruhr se vê com um imenso legado industrial obsoleto, esvaziado e em ruínas. Os pesquisadores Berger e Wicke ${ }^{30}$ mencionam a descoberta desse patrimônio em meio à mudança de clima ideológico e estético nos anos 1960, contexto que teria colaborado para que se levasse a sério o passado industrial e, sobretudo, o cotidiano dos trabalhadores, cujo modo de vida aparece como mediação para lastrear o que eles definem como êxito do patrimônio industrial na Renânia do Norte-Vestfália, com um programa de preservação de edifícios tecnológico-históricos que reagiu à morte previsível do setor minerador. A convergência de recursos públicos na aquisição de propriedades industriais, a mobilização do Estado na preservação e na incorporação das antigas áreas industriais no planejamento urbano e a participação da população nos movimentos pró-preservação do patrimônio industrial foram fundamentais na definição da identidade regional, inclusive a partir de projetos como o Museu da Mineração Alemão, cuja visita guiada pode ser feita, atualmente, por um ex-engenheiro especializado em mineração; ${ }^{31}$ - Museu Industrial da Vestfália, com sítios descentralizados em complexos mineradores; e o Museu Industrial Renano (atual LVR-Industriemuseum), instalado em uma antiga fábrica de zinco em Oberhausen. A iniciativa da lba Emscher Park, agência criada pelo governo regional e que trabalhou pela reconversão do legado industrial, incorporou também a dimensão imaterial desse patrimônio, presente nos alimentos, nos esportes, nos conflitos, no companheirismo entre os mineiros e nos bares públicos das esquinas. A região viveu pressões para a demolição de boa parte das edificações fabris, mas a mobilização regional e a argumentação em prol da manutenção de uma identidade industrial e sua importância na própria sustentação do desenvolvimento alemão não só permitiram sua preservação, inclusive em nível mundial - Zollverein tornou-se patrimônio da humanidade pela Unesco em 2001 -, como sua utilização na base da nova economia local. Quatrocentos quilômetros de estradas e setecentos de ciclovias formam uma Rota do Patrimônio Industrial englobando uma série de pontos de valorização do patrimônio industrial, entre vilas operárias e ex-fábricas, além de perspectivas cênicas, rotas temáticas específicas, atrações de verão, exposições e variadas oportunidades de lazer, além de edificações históricas adaptadas para abrigar escritórios de companhias da região. Em 2010, Ruhr foi a Capital Europeia da Cultura. ${ }^{32}$ 
No norte da Itália, a ex-fábrica Fiat Lingotto, em Turim, foi uma experiência paradigmática de reconversão do patrimônio industrial. Projetada em 1915 e desativada em 1982, assumiu elevado valor histórico, cultural e simbólico. Seus 18 hectares de área passaram por um longo processo de requalificação, tendo sido reprojetada por Renzo Piano para uma utilização polifuncional, associando funções terciárias, comerciais e culturais. Seus usos atuais contemplam centro de eventos, auditório, escritório, hotel, área verde, estacionamento, heliporto, cinema, shopping center, clínica odontológica da Universidade de Turim, sede administrativa da Fiat e um Centro de Pesquisa e Treinamento em Engenharia Automotiva do Politécnico de Turim, ${ }^{33}$ mantendo viva, de alguma forma, a memória do trabalho no reúso do patrimônio industrial como espaço de formação profissional.

No Reino Unido, o Ironbridge Gorge Park é um território síntese do desenvolvimento industrial da Inglaterra, já bastante desenvolvido tecnologicamente em fins do século XVIII, hoje convertido para a oferta turística e cultural. A região de Coalbrookdale foi rica em carvão e minério de ferro e tornou-se referência na produção de ferro da Grã-Bretanha, com a instalação de um complexo com fornos, forjas e residências de uma série de trabalhadores como fundidores de chumbo, ferreiros, fabricantes de vidro e oleiros ao longo dos séculos XVII e XVIII. Além da ponte que the é referência, construída em ferro fundido em 1779, a área reúne a sede da Coalbrookdale Company, restaurada em 2001 e inaugurada em 2002 como Centro Interativo de Design e Tecnologia e Museu, o Enginuity; fornos de garrafas Coalport, restaurados em 2016; o Coalport China Museum, inaugurado em 1977; o Museu do Ferro, aberto ao público em 1979; o ecomuseu de Blists Hills Open Air Museum, inaugurado em 1973; um centro de visitantes, além de galerias, áreas de exposições e eventos, shows interativos e uma diversidade de atividades culturais e de lazer. Em 1986, o Ironbridge Gorge foi designado Patrimônio Mundial dentro do Reino Unido, reconhecendo-se a contribuição da área para a Revolução Industrial. ${ }^{34}$

Nesse contexto, é também bastante emblemática a criação, em 1974, do Écomusée du Creusot Montceau-Les-Mines, na região francesa de Borgonha, um território marcado pela metalurgia, mineração de carvão, fabricação de vidro e cerâmica. Suas técnicas de forja e fundição colocaram Le Creusot entre importantes centros industriais. Essa experiência opera pela primeira vez o conceito de ecomuseu ${ }^{35}$ ao criar o Museu do Homem e da Indústria e passa a referenciar uma nova forma de musealizar o patrimônio industrial, inclusive reposicionando o papel das comunidades que o abrigam. Uma nova estrutura institucional foi criada para permitir o maior acesso possível da coletividade aos meios de apropriação do patrimônio, marcando uma experiência que promoveria uma reviravolta na museologia francesa e mundial. ${ }^{36}$ Nessa perspectiva participativa, o ecomuseu
33. Cf. Museotorino (2019).

34. Cf. Ironbridge Gorge Museums (2019).

35. Embora esta experiência tenha se tornado um marco no conceito de ecomuseu, convém lembrar da estreita relação deste conceito no contexto das discussões sobre a proteção do meio ambiente que emergiram a partir da Conferência de Estocolmo, em 1972. Para detalhes a respeito da relação da Museologia com a área ambiental, cf. Guerra; Vasconcellos (2018).

36. Cf. Soares (2015). 
37. Cf. Écomusée-Creusot-Montceau (2019).

38. Em Patrimônio industrial como tema de pesquisa, Cristina Meneguello (2011) faz uma síntese dos diferentes campos de investigação associados ao patrimônio industrial e também da trajetória dos estudos sobre o tema.

39. Cf. Gottdiener (1993); Glazer (1972); Castells (1983); Harvey (1994).

40. "As técnicas são um conjunto de meios instrumentais e sociais, com os quais o homem realiza sua vida, produz, ao mesmo tempo, cria espaço [...] Sem dúvida, a técnica é um elemento importante de explicação da sociedade e dos lugares, mas sozinha, a técnica não explica nada. Apenas o valor relativo é valor." Santos (2009, p. 45-46).

41. O termo remete à gentry, classe social inglesa incorporada à nobreza, cf. Baudemont,1993, onde a autora adentra os detalhes dos ritos sociais que caracterizaram este grupo, sobretudo suas práticas culturais e de lazer e seus espaços de exibição por excelência. Silvana Rubino lembra que, duas décadas depois de ter sido usado pela primeira vez por Glass, nos anos 1950, o termo gentrification passou a constar dos dicionários de língua inglesa, revelando a necessidade de nomear aquilo que já se identificava como prática social. Com o termo "enobrecimento", remete-se aos "novos nobres que ocupam espaços urbanos" (Rubino, 2009, p. 38). Rubino refere-se a uma "modalidade contemporânea de higienismo" (Ibid., p. 37), "gentrification / enobrecimento, assim como revitalização, requalificação e outros termos análogos [...] eufemismos para uma forma contemporânea de limpeza urbana [...]" (Ibid., p. 35). salvou e aprimorou locais de interesse patrimonial, constituindo importantes coleções que não só atestam a civilização industrial como servem de instrumento para o conhecimento e a compreensão da identidade cultural dos homens. ${ }^{37}$

As experiências de identificação, proteção e refuncionalização do patrimônio industrial se propagam por outros países e continentes. $\bigcirc$ surgimento de associações da sociedade civil, o desenvolvimento de pesquisas e o crescente interesse da comunidade acadêmica e a ocorrência de uma série de encontros internacionais sobre o tema atestam sua importância. ${ }^{38}$ No caso de São Paulo, e tendo como referência os levantamentos realizados para subsidiar este texto, limitamo-nos a balizar as análises pelo reúso de antigas fábricas que i) evidenciam - descompasso entre a temporalidade das ações de preservação da memória industrial adotadas pelas instituições formais públicas e os interesses particulares, notadamente do mercado imobiliário; ii) denotam efeitos perversos decorrentes do tratamento meramente formal-estético que muitas vezes ainda orienta o Estado na seleção dos bens alvo de ações de preservação ou mesmo da sua postura quase sempre reativa à destruição iminente, já que as políticas preservacionistas nem sempre dão conta de, diante do risco de desaparecimento, antecipar formas de salvaguardar tal memória tendo em vista contemplar uma cultura mais geral dos trabalhadores, de um sistema de vida que, além do trabalho, também supõe divertirse, relacionar-se, morar, deslocar-se; iii) colocam em cena os atores em disputa pelo território das fábricas e os aspectos que interferem no seu jogo de forças.

\section{LEGADO INDUSTRIAL NA ZONA LESTE DE SÃO PAULO: REQUALIFICAÇÃO DO PATRIMÔNIO E TERRITÓRIO}

A requalificação, que também pode ser entendida como uma refuncionalização ou reabilitação de edificações, nesse caso industriais, visa criar uma nova função para esse imobiliário no contexto da economia de serviços. Ocorre em pontos estratégicos da cidade com vistas a catalisar novas atividades econômicas que permitam reinserir porções do território no circuito econômico de forma competitiva, por meio de intervenções públicas, privadas ou realizadas de forma conjunta entre esses dois agentes. Embora a gênese de processos desse tipo tenha ocorrido nos Estados Unidos entre os anos 1940 e 1960, ${ }^{39}$ ganham força e passam a ser assim nomeados, enquanto "técnica" 40 e com maior frequência, a partir dos anos 1970 e 1980, ocorrendo então em diferentes cidades do mundo. Seu resultado, em geral, tem sido a gentrification ${ }^{41}$ das áreas 
e/ou imóveis reabilitados e suas áreas envolventes, o que vem tornando essas operações cada vez mais atraentes para reinserir num novo ciclo econômico áreas urbanas que perderam vigor no processo de reestruturação produtiva, ${ }^{42}$ depreciaram-se e acabaram por ser ocupadas por moradores e usuários de baixo poder aquisitivo. Se, por um lado, o reconhecimento desta ação remete a um processo de difusão rápida e generalizada dessa "técnica", "é o lugar que atribui às técnicas o princípio da realidade histórica, relativizando seu uso, integrandoas num conjunto de vida, retirando-as de sua abstração empírica e thes atribuindo efetividade histórica", ${ }^{43}$ e, "em nenhum caso a difusão dos objetos técnicos se dá uniformemente ou de modo homogêneo, essa heterogeneidade vem da maneira como eles se inserem desigualmente na história e no território, no tempo e no espaço". ${ }^{44}$ Pois bem, a requalificação de imóveis fabris obsoletos não ocorre de forma homogênea em toda a cidade, tampouco em toda a zona leste.

Também é importante tratar das especificidades da preservação do patrimônio industrial. A inclusão dessa tipologia de produção arquitetônica no conjunto de bens a serem preservados levanta questões particulares, dentre as quais sua reutilização para reintegração na dinâmica urbana, pois se o desuso de edificações históricas significa um risco para sua integridade, o desgaste e a usurpação de novos usos podem ser igualmente danosos. ${ }^{45}$ Para Choay, os edifícios de construções sólidas, sóbrias, de fácil manutenção, que caracterizam a herança industrial fora de uso, são facilmente adaptáveis às utilizações atuais e podem se prestar a múltiplos usos; carregam valores afetivos de memória importantes para aqueles que aí se territorializaram e construíram seus horizontes, além de ter valor documental. Contudo, sua preservação material parece ser ilusória, especialmente por sua escala num contexto de urbanização e reorganização de territórios. ${ }^{46}$

A própria industrialização já havia introduzido a ideia das coisas descartáveis e essa mesma lógica incide sobre a questão urbana, transferindo o valor das edificações para os terrenos e consequentemente contaminando a ideia de patrimônio como uma relíquia que deve sobreviver à destruição, já que o valor dos imóveis não é maior do que o valor dos terrenos, sobretudo se inseridos em áreas de boa infraestrutura, conectadas a eixos importantes de mobilidade e com alto potencial construtivo em áreas metropolitanas densas. Dessa forma, os tipos de uso e de agentes a se envolverem nos processos de requalificação e a correlação de forças entre eles dependerá dos atributos da localidade onde ocorre e da mediação da cultura local, entendida como os diferentes níveis de participação dos grupos sociais envolvidos, das heranças históricas e das práticas políticas peculiares de cada localidade.

A preservação desse patrimônio, portanto, tem estado cada vez mais submetida a reutilizações que possam render recursos capazes de manter a
42. Cf. Smith (2006); Harvey (1994).

43. Santos (2009, p. 58).

44. Ibid., p. 39.

45. Choay (2001, p. 219).

46. Ibid., p. 219-220. 
47. Dos bens tombados pelo Iphan em São Paulo, identificam-se raros exemplares da arquitetura relacionados de alguma forma ao período de industrialização da cidade: a Estação da Luz, tombada em 1996 (pedido feito em 1976); prédio da estação Júlio Prestes (processo instruído em 1997); Sesc Pompeia, tombado em 2015; locomotivas elétricas e subestações de energia remanescentes do Sistema Ferroviário Eletrificado do Estado de São Paulo (processo instruído em 2017). Seleção feita a partir da Lista de Bens Tombados do Iphan, disponível em: $<$ https://bit.ly/3fMYpcP>.

48. Imóveis tombados na categoria Industrial e Fabril pelo Condephaat na cidade de São Paulo (considerada a data da resolução e informada entre parênteses a data de inscrição no livro do tombo, quando diferente): Antiga Fábrica de Tecidos Labor, tombada em 2014; Conjunto dos Grandes Moinhos Minetti Gamba, tombados em 2013; Indústrias Reunidas Francisco Matarazzo, tombadas em 1986 (1987); Matadouro de Vila Mariana, tombado em 1985 (1987); Complexo do Gasômetro e Casa das Retortas, tombados em 2010. Na categoria Assistência e Saúde, tomba-se em 1982 a Hospedaria dos Imigrantes e em 1995 o Edifício da Associação Auxiliadora das Classes Laboriosas (1996), tendo sido também em 1982 tombado na categoria Acervo Artístico e Documental, o Acervo Arquivístico da Hospedaria dos Imigrantes. A ETEC Carlos de Campos foi tombada na categoria Educação e Pesquisa em 2010 (2011). O Edifício Conde Matarazzo foi tombado em 2015 e o Palácio das Indústrias em 1982, ambos na categoria Administração Pública. Na categoria Patrimônio Ferroviário estão o Acervo da Estrada de Ferro Perus-Pira- integridade das edificações ou, como é mais comum, de suas fachadas, ou sob o risco de demolições que desobstruam áreas de interesse para novos empreendimentos. O Estado mostra-se aí um ator dos mais relevantes na manutenção do patrimônio industrial, na seleção do que e como preservar, seja por seu protagonismo à frente das políticas de patrimônio material desde sua concepção, seja por sua participação nos embates ałuais entre mercado e sociedade a respeito da destinação dos imóveis fabris ou dos seus terrenos para novos usos.

Ao observar a atuação das instituiç̃ões públicas no reconhecimento oficial e na preservação do imobiliário fabril em São Paulo, são pontuais as ações nas três esferas de governo. Os tombamentos de edificações industriais em nível federal na cidade de São Paulo são praticamente inexistentes ${ }^{47}$ e, embora a partir dos anos 1980 se verifiquem esforços para ampliar o conceito de patrimônio cultural e superar os cânones artísticos do período colonial que por muito tempo orientaram as ações preservacionistas, para então abranger outros momentos da nossa produção arquitetônica, mesmo na escala estadual, os tombamentos de exemplares industriais na cidade são todavia acanhados ${ }^{48}$ e enfrentam os fortes interesses do mercado imobiliário pelo valor dos terrenos onde se encontram. Dos remanescentes das Indústrias Reunidas Francisco Matarazzo, primeiro exemplar tombado de uma fábrica em nível estadual, sobraram apenas a casa de máquinas e as chaminés. As demais edificações foram demolidas para dar lugar a novos empreendimentos imobiliários. Nesse sentido, é emblemático o caso do conjunto de 35 casas construídas nos anos 1950 no Tatuapé para atender trabalhadores que afluíam a essa região, atraídos pelo trabalho operário, demolidas em setembro de 2019.49 A cidade de São Paulo, destinada a se verticalizar quase completamente, excetuando-se poucos conjuntos de casas preservados em certos bairros, faz desaparecer formas de construir e habitar, além de amputar parte do sistema de produção e ocupação da cidade vinculada ao processo de industrialização, que são os espaços de morar dos operários. Raquel Rolnik reconhece que esse tipo de proteção não deveria ser deixado exclusivamente sob responsabilidade de tombamento por parte dos órgãos de patrimônio, pois numa cidade cujo sistema de regulação e uso do solo não prevê que casas devam ser mantidas e não dar lugar à construção de edifícios, gera-se uma expectativa enorme seja nos proprietários dos imóveis seja no mercado construtor, recaindo especialmente na cobiça pelos terrenos onde se localiza esse tipo de construção sem grandes excepcionalidades artísticas ou arquitetônicas. ${ }^{50}$

Em nível municipal também não são numerosos os tombamentos de remanescentes industriais, não obstante tenham sido feitos estudos relevantes para a identificação desse patrimônio. Paula Andrade ${ }^{51}$ identifica dois inventários importantes originados com os estudos do patrimônio ambiental da região leste por ocasião da implantação do metrô: Cura ${ }^{52}$ Brás-Bresser e o Patrimônio Ambiental 
Zona Metrô-Leste, ambos realizados entre os anos 1977 e $1978 .{ }^{53}$ Esse vasto diagnóstico envolvendo a Empresa Municipal de Urbanização (Emurb), a Coordenadoria Geral de Planejamento (Cogep), órgão então responsável pelo planejamento da cidade e preservação do patrimônio, e o Departamento de Patrimônio Histórico (DPH), identificou uma série de vilas, conjuntos habitacionais e galpões industriais, mas não desencadeou processos de preservação que correspondessem ao que foi apontado nos inventários e vários imóveis, identificados nessa ocasião, desapareceram com o processo de transformação da zona leste. ${ }^{54}$ Aliás, se demoliu muito mais do que o necessário à construção do metrô, indicando a intenção de acelerar a valorização do solo e atrair investimentos para a região. ${ }^{55}$ Por ocasião desses estudos, apenas entre os bairros do Brás e Mooca, foram identificados 189 galpões industriais representativos da primeira fase da industrialização paulistana. ${ }^{56}$ A experiência adquirida pelo DPH nesse processo permitiu que fosse instituído no Departamento o Inventário Geral do Patrimônio Ambiental, Cultural e Urbano de São Paulo (lgepac), iniciado em 1982 com o propósito de ser um levantamento contínuo, inclusive superando o enfoque tradicionalmente centrado nos edifícios considerados isoladamente, pretendendo integrar políticas de desenvolvimento e não apenas subsidiar tombamentos. ${ }^{57}$ Para alguns especialistas, entre os aspectos socioculturais presentes dos inventários, estava ausente, todavia, uma dimensão intangível da cultura, ${ }^{58}$ apresentando, por fim, poucas possibilidades de penetração nas políticas urbanas. ${ }^{59}$

Conpresp, em 1988, reconhece em escala municipal todos os imóveis tombados nas esferas federal e estadual, aos quais foram acrescentados outros exemplares da arquitetura industrial. ${ }^{60}$ Ainda que tímido, cabe destacar o avanço nas ações de preservação com a inclusão de imóveis industriais em Zepecs, ${ }^{61}$ o que revela alguma preocupação com a ambiência urbana na qual se encontram e sua relevância para a compreensão do desenvolvimento urbano associado aos processos de industrialização em São Paulo. Contudo, são enormes as descaracterizações desse imobiliário fabril, não obstante os tombamentos efetivos, os processos de tombamento em andamento ou a sua inclusão em áreas urbanas que implicam maior preservação. Se observarmos as datas dos tombamentos dos bens elencados nas listas destes órgãos lem particular do Conpresp, cuja escala supõe maior preocupação com a manutenção desse patrimônio industrial tão importante para a formação da cidade), chama a atenção a morosidade das ações de preservação por parte do Estado e os longos períodos sem nenhuma ação efetiva de proteção. ${ }^{62}$ Mesmo nos casos em que há tombamento, não tem sido capaz de proteger esse patrimônio em conformidade com as diretrizes da Carta de Nizhny Tagil para o Patrimônio Industrial, que recomenda a proteção das "fábricas e suas máquinas, os seus elementos subterrâneos e as suas pora, tombada em 2000 (1987); a Antiga Estação Júlio Prestes, tombada em 1999 (2000); o Conjunto Ferroviário de Perus, tombado em 2011 (2012); a Estação da Luz, tombada em 1982; a Estação de Bondes do Brás, tombada em 2008 e a Estação do Brás, tombada em 1982. Na categoria residencial, estão a Vila Economizadora, tombada em 1980 (1981); a Vila Maria Zélia, tombada em 1992 (1983). Lista de Bens Protegidos do Condephaat, disponível em: <http://condep h a a t . s p . gov . b r / bens-protegidos-online/>

49. Expansão imobiliária na Zona Leste de São Paulo faz vila histórica desaparecer. Folba de São Paulo, 4 de setembro de 2019. Disponível em: <https:// www1.folha.uol.com.br/ cotidiano/2019/09/expansao-imobiliaria-na-zona-leste-de-sp-faz-vila-historica-desaparecer.shtml>

50. Cf. Rolnik (2019).

51. Cf. Andrade (2012).

52. Refere-re ao programa do governo federal chamado Comunidades Urbanas de Recuperação Acelerada CURA, do Banco Nacional de Habitação (BHN), ao qual a prefeitura de São Paulo aderiu para a viabilização financeira das obras de reubanização vinculadas à construção do trecho leste do metro. Cf. Andrade (2012).

53. Id.

54. Para detalhes sobre este processo de diagnóstico, inventários, documentos produzidos e equipes integrantes cf. Andrade (2012).

55. Arquiteta Bartira Costa apud Andrade (2012, p. 116).

56. Rufinoni (2016, p. 225). 
57. Cf. Andrade (2012); Rodrigues (2011).

58. Castriota apud Rufinoni (2016, p. 226).

59. Cf. Santana (2019).

60. Antiga Estação do Brás da São Paulo Railway (1991); Matadouro de Vila Mariana (1991); Indústrias Reunidas Francisco Matarazzo (1991); Estação da Luz (1991);Vila Economizadora (1991); Antiga Cia Brasileira de Cimento Portland Perus, Vila, Estação de Ferro Santos Jundiaí, Área da Antiga Estrada de Ferro Perus - Pirapora (1992); Moinho Matarazzo (1992); Tecelagem Mariângela (1992); Antiga Fábrica Maria Zélia Cia Goodyear do Brasil e Vila Maria Zélia (1992); Galpões da Antiga Fábrica UNILABOR (2004), Tendal da Lapa (2007); Antigas Oficinas da Sociedade Anônima Casa Vanorden (2007); Antigo Conjunto de Depósitos para Café (2007); Antigo Conjunto Grandes Moinhos Minetti Gamba (2007); Antigo Conjunto Sociedade Técnica Bremensis e Schimidt Trost (2007); Conjunto de Armazéns da Antiga São Paulo Railway (2007); Galpão Industrial da Rua Borges de Figueiredo (2007); Antiga Cooperativa de Cotia (2009); Fábrica de Vidraria Santa Marina (2009); Galpão Fabril da Antiga Metalúrgica Martins Ferreira (2009); Antiga Fábrica de Tubos de Barro (2009); Cia Melhoramentos de São Paulo (administração) (2009); SESC Pompéia (2009); Estação Ciência (2009); Chaminé da Cia de Refinadores UNIÃO (2010). Relação feita a partir do trabalho de Rodrigues (2011), baseada nos dados do Conpresp disponíveis em <http://www.prefeitura.sp.gov. br/cidade/secretarias/cultu$\mathrm{ra} / \mathrm{conpresp/indice \_ geral/}$ index.php? $\mathrm{p}=1142>$ e consultados por Rodrigues em 25 out. 2010. Acrescenta-se a esta lista, tombamentos realizados pelo Conpresp na estruturas no solo, os complexos e os conjuntos de edifícios, assim como as paisagens industriais". No caso de novos usos, a Carta recomenda "respeitar o material específico e os esquemas originais de circulação e produção, sendo quanto possível compatíveis com a sua anterior utilização", sendo "recomendável uma adaptação que evoque a sua antiga atividade". ${ }^{63}$ Ou seja, tanto os atos de proteção legal quanto as reutilizações que visam sua conservação não têm sido suficientes. A perda desse território por parte do Estado e a dificuldade cada vez maior de reconstituirmos os processos de urbanização em função da ausência de registros dos diferentes momentos da industrialização na cidade são claras. Confrontam-se aí duas temporalidades, o tempo rápido dos interesses do mercado imobiliário e o tempo lento e a seletividade dos tombamentos por parte das instituições públicas, além do pouco alcance dos instrumentos de regulação e uso do solo urbano na preservação cultural.

Verificam-se algumas ações da sociedade civil que tem se organizado e participado da disputa por esses espaços, mas nem sempre são capazes de fazer as decisões penderem a seu favor. A criação do Território de Interesse da Cultura e da Paisagem (TICP), 64 incorporado à política municipal em 2014 por meio do Plano Diretor estratégico de São Paulo a partir de proposições da sociedade civil, 65 por exemplo, permanece sem regulamentação, tendo sido estabelecido apenas no eixo Paulista/Luz e Jaraguá/Perus, ainda sem demarcação oficial e sem implementação. ${ }^{66}$

\section{AGENTES DA REQUALIFICAÇÃO DO PATRIMÔNIO INDUSTRIAL E A DISPUTA EM TORNO DO SEU USO: EXPLORANDO A EMPIRIA}

Para o estudo de caso da cidade de São Paulo, selecionamos alguns dos imóveis tombados para verificar in loco o uso que lhes tem sido atribuído. Não serão abordadas questões relativas aos aspectos teórico-metodológicos, nem técnico-operacionais aplicados, ou não, aos exemplares do patrimônio industria| ${ }^{67}$ indicados. A intenção é apenas identificar nos seus usos atuais como vem se dando sua apropriação e seu alcance na salvaguarda do patrimônio industrial em suas múltiplas dimensões e em que medida a refuncionalização de seus edifícios reforça a hipótese da reconversão econômica. Quem ganha e quem perde com a requalificação do patrimônio industrial em certos distritos da zona leste?

O Moinho Matarazzo (figura 1) foi inaugurado em 1900 e funcionou até 1970. Utilizado para moagem e estocagem de trigo e algodão, foi tombado pelo Conpresp em 1992. Exemplar emblemático do primeiro período da industrialização de São Paulo e da obsolescência dos espaços fabris tradicionais na cidade. 
Evidencia uma preservação fetichista, na medida em que nada além da "casca" foi preservada in situ. Maquinário, produtos, iconografia, memória dos funcionários inexistem no local. Em 2003, foi reutilizado como restaurante (Restaurante Santa Rosa) e espaço para eventos (abrigou, por exemplo, a Festa Halloween da grife Auslander, em 2015, e o desfile de moda da grife Cavalera, em 2016). A edificação histórica aqui tem status, conferindo notoriedade às novas atividades, que por sua vez transformam o capital cultural desse patrimônio em capital econômico. São empreendimentos de prestígio voltados a um público selecionado, colocando a "função social" desse patrimônio em questão. São usos que apontam para a presença do setor de serviços na antiga fábrica, sendo os eventos extremamente relevantes para a economia da cidade de São Paulo, como já pudemos evidenciar. ${ }^{68}$

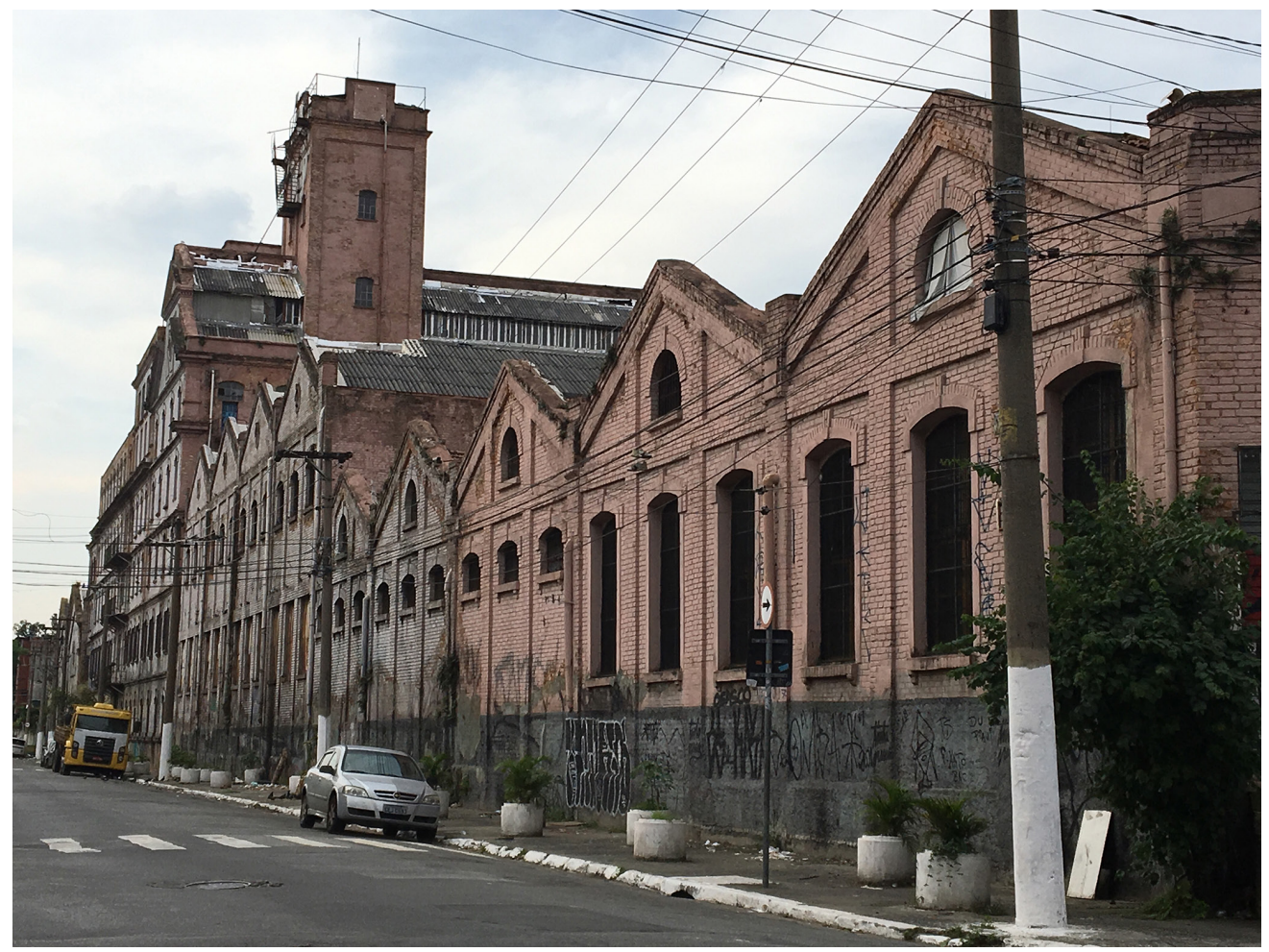

Figura 1 - Moinho Matarazzo, maio 2019. Fotografia: Clarissa M. R. Gagliardi.

A mesma lógica se aplica aos Moinhos Minetti e Gamba (figura 2), construídos em 1909 no bairro da Mooca. Desativados nos anos 1960, suas edificações ficaram vazias até se converterem na casa noturna Moinho Santo Antônio, em 1994. Tombado pelo Conpresp em 2007 e pelo Conpedhaat em 2013, o local foi convertido em espaço para eventos de 2000 a 2013 e em 2014 teve início um projeto para a instalação de uma faculdade particular no última década na zona leste: a Companhia Nitro Química Brasileira (2012); Casa das Retortas (2012); Fábrica Labor (2014); Estação de Bondes do Brás (2014); Conjunto de Residências Operárias do Jardim Matarazzo (2016); Vila Andrea Raucci (2016); Fábrica Orion (2016); Tecelagem de Seda Ítalo-Brasileira (2017); Cotonifício Crespi (2017); Armazéns Gerais Piratininga (2018); Centro Cultural Casa da Memória ("Casa do Chefe da Estação”, 2019), cf Sistema de Consulta do Mapa Digital da Cidade de São Paulo, disponível em $<$ http://geosampa.prefeitura. sp.gov.br/PaginasPublicas/_ SBC.aspx\#>

61. "As ZEPEC's (Zonas Especiais de Preservação Cultural) são porções de território destinadas à preservação dos bens de valor histórico, artístico, arquitetônico, arqueológico e paisagístico. Ao integrarem uma ZEPEC, esses territórios tornam-se patrimônios culturais”. Cf. DPH (s. d.).

62. Alguns exemplos atestam o longo intervalo entre a desativação das fábricas e seu tombamento: Indústrias Reunidas Francisco Matarazzo, desativadas em 1975 e tombadas pelo Condephaat em 1986 e pelo Conpresp em 1991; o Moinho Matarazzo e a Tecelagem Mariângela, desativados desde os anos 1970 e tombados pelo Conpresp apenas em 1992; o antigo conjunto dos Grandes Moinhos Minetti e Gamba, desativados nos anos 1960 e tombados pelo Conpresp em 2007 e pelo Condephaat somente em 2013; Antiga Fábrica de Tecidos Labor, desativada em 1987 e tombada pelo Condephaat e pelo Conpresp em 2014.

63. Cf. Ticcih (2018).

64. O Artigo 314 do Plano Diretor Estratégico define o TIP como "áreas que concentram grande número de es- 
paços, atividades ou instituições culturais, assim como elementos urbanos materiais, imateriais e de paisagem significativos para a memoria e a identidade da cidade, formando polos singulares de atratividade social, cultural e turística de interesse para a cidadania cultural e o desenvolvimento sustentável, cuja longevidade e vitalidade dependem de ações articuladas do Poder Público. $\S 1^{\circ}$ Os TICP devem ser constituídos por sua importância para a cidade como um território simbólico que abriga áreas ou um conjunto de áreas naturais ou culturais protegidas, lugares significativos para a memória da cidade e dos cidadãos e instituições de relevância cultural e científica”. Cf. Prefeitura do Município de São Paulo (2014).

65. Danielle Cristina Dias de Santana identifica em sua pesquisa de mestrado a formulação do TICP a partir de propostas apresentadas pelo Movimento pela Reapropriação da Fábrica de Cimento de Perus em conjunto com o Núcleo de Estudos da Paisagem do Laboratório Cidade da FAU-USP, cf. Santana (2019).

66. Id.

67. Para este tema, cf. Kühl (2009).

68. Cf. Carvalho et al. (2018).

69. Disponível em: <https:// www.amoamooca.org.br.> imóvel, conforme atesta o canteiro de obras implantado (figura 3). Os moradores do entorno, insatisfeitos com o simples centro de exposições que o novo empreendimento reservou para a comunidade como contrapartida, pleiteiam maior uso da edificação e questionam o impacto que a nova atividade gerará no bairro. A Mooca constitui hoje um dos distritos onde a transformação da paisagem cultural e os processos de requalificação são mais pujantes. Se, de um lado, atrai o mercado imobiliário, por outro, há forte mobilização de moradores para preservar o patrimônio, demonstrando a disputa pelo valor expresso no capital cultural ali presente. É sintomática a fundação da associação Amo a Mooca em 2001, ano em que a empresa BRMalls adquiriu o terreno de 72 mil metros quadrados da Fábrica de caminhões da Ford, demolida em 2009 para dar lugar ao shopping center Mooca Plaza Shopping. A Amo a Mooca reúne-se mensalmente e ałua em favor da preservação do bairro da Mooca. Elencam entre suas conquistas uma sede para a associação entre os galpões da rua Javari e os tombamentos do Cotonifício Crespi e dos Moinhos Minetti e Gamba. ${ }^{69}$

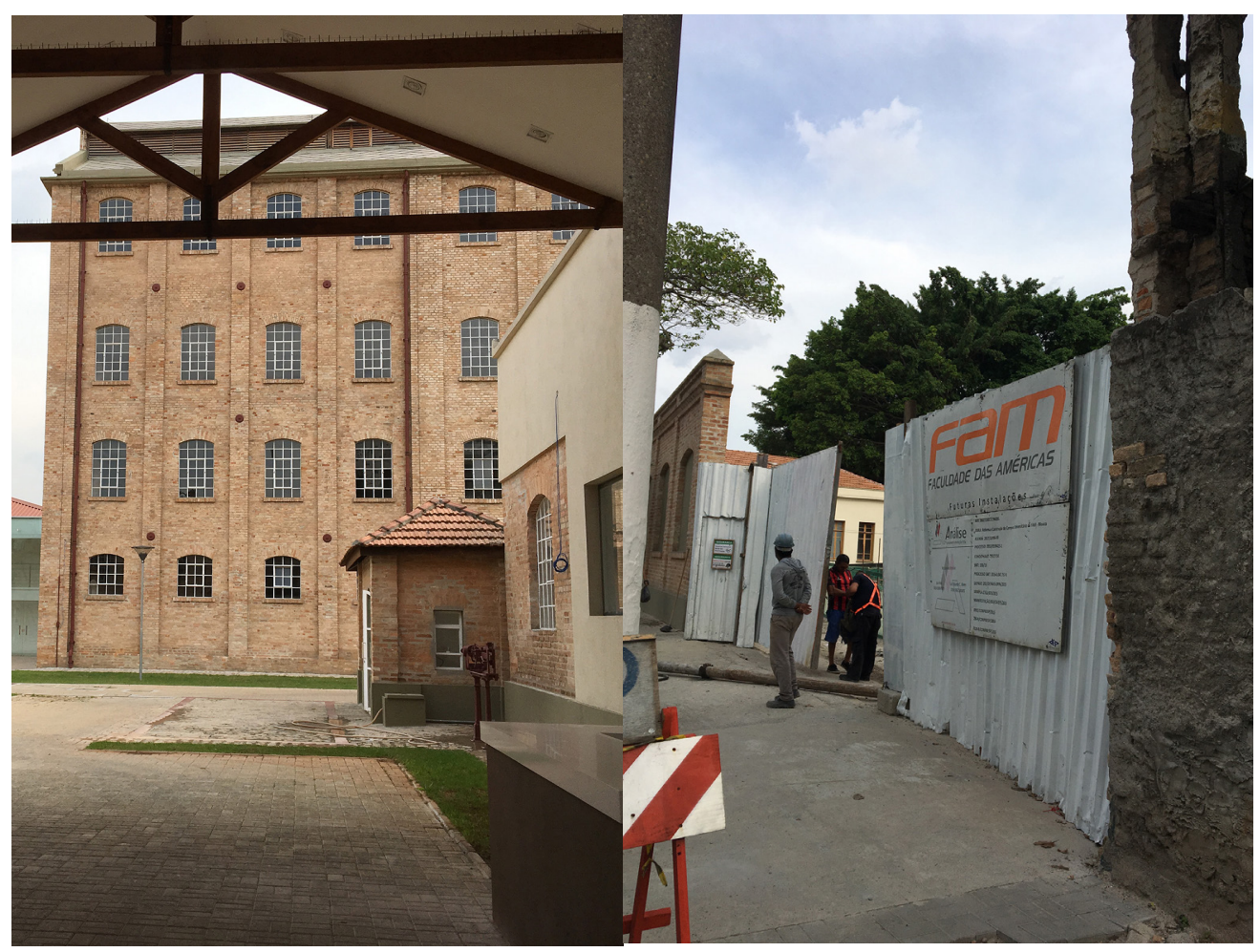

Figuras 2 e 3 - Um dos moinhos Minetti e Gamba e entrada do canteiro de obras da Faculdade das Américas, instituição de ensino que funcionará nas antigas instalações do Moinho, maio 2019. Fotografia: Clarissa M. R. Gagliardi 
Cotonifício Crespi (figura 4) foi inaugurado em 1897 e desativado em 1963. Ficou abandonado até 2003, quando a rede de hipermercados Extra o adquiriu. Manteve-se apenas a fachada preservada, por determinação do DPH e do Ministério Público. Seus operários fundaram o Clube Juventus, em 1924, que resiste no bairro e lembra os espaços de lazer e sociabilidade daqueles trabalhadores, sendo ainda hoje um local de encontro para os moradores do bairro. A entrada dos grandes hipermercados na zona leste pode também ser tomada como um indicador da reconversão econômica. ${ }^{70} \mathrm{~A}$ versatilidade das edificações e galpões de antigas fábricas pode, inclusive, favorecer instalações desse gênero, garantindo de alguma forma a manutenção de sua aparência externa, ainda que isso não seja suficiente para a rememoração plena do sentido daquela fábrica. Um painel com fotos da antiga fábrica foi disposto junto às escadas rolantes (figura 5) para ser visto de passagem, numa irônica metáfora do caráter transitório da cidade.

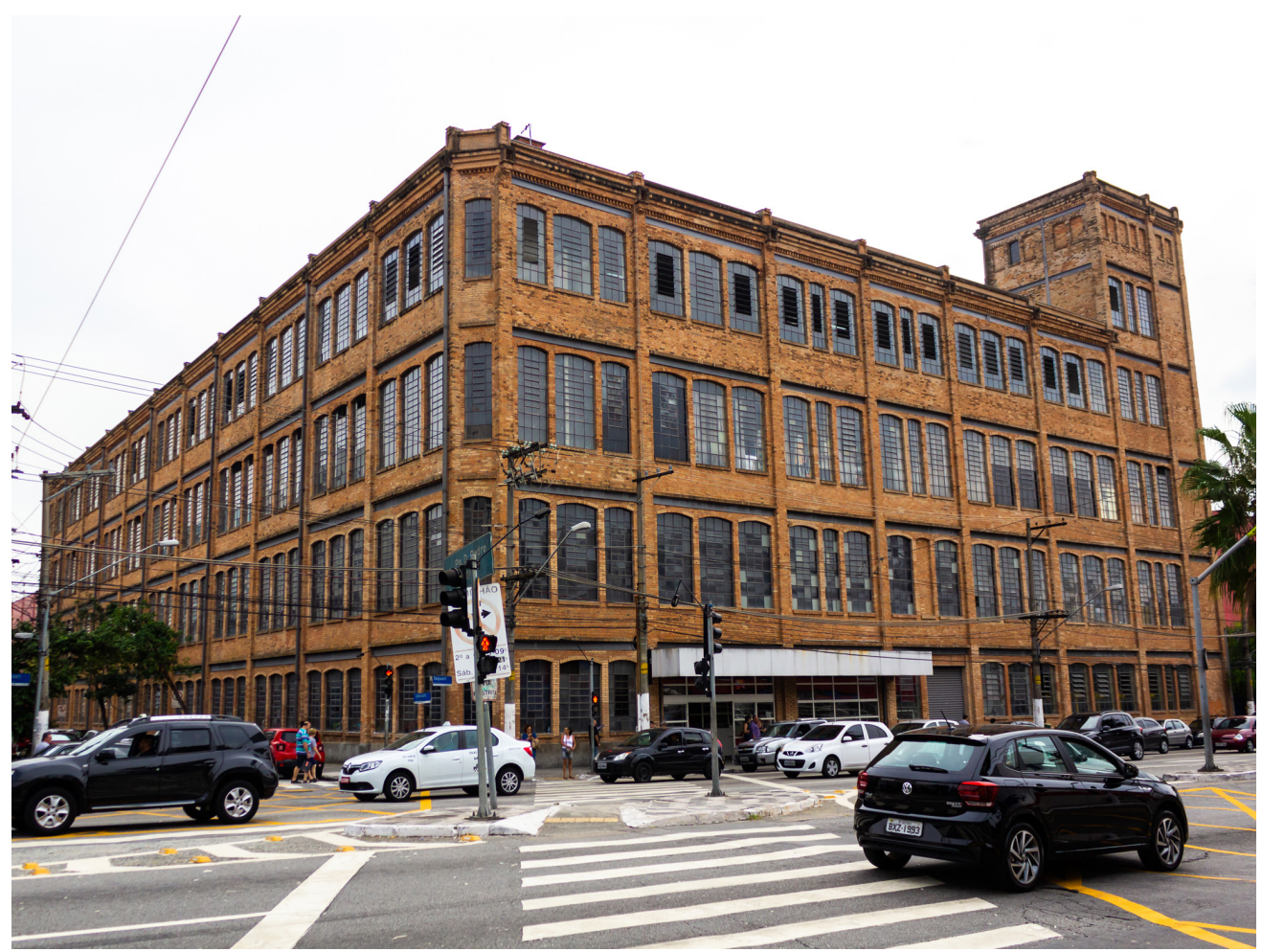

Figura 4 - Fachada lateral do edifício do antigo Cotonifício Crespi, maio de 2019. Fotografia: Carolina Figueiredo Lourenção.

No mesmo bairro, a Fábrica União, fundada em 1910 e desativada em 2006, representa a assimetria da disputa em torno dos grandes terrenos das ex-
70. Cf. Rolnik; Frugoli (2001). 
71. Resolução No 07/CONPRESP/2008, cf. Conpresp (2008).

72. Imóvel de antiga fábrica e balada na Mooca vira invasão sem-teto. Folha de São Paulo, 13 set. 2018. Disponível em: <https://www1. folha.uol.com.br/cotidiano/2018/09/imovel-de-antiga-fabrica-e-balada-na-mooca-vira-invasao-sem-teto. shtml>

73. Processo de tombamento da Antiga Fábrica de Tecidos Labor. Cf. Condephaat (s. d.) fábricas. Foi completamente demolida, em 2014, para dar lugar ao empreendimento imobiliário Luzes da Móoca, cujas peças promocionais remetem o potencial morador do condomínio à tradição industrial do bairro, ao seu capital cultural, não obstante tenha sido preservada apenas a chaminé da antiga fábrica (figura 6), único bem tombado em 2010, e ainda que o processo de tombamento tenha considerado o patrimônio industrial um "aglutinador de importantes valores históricos, sociais, tecnológicos e arquitetônicos, testemunhos das técnicas construtivas tradicionais e dos processos produtivos dos primórdios da industrialização paulista". ${ }^{71}$ Próximo a este empreendimento, na Rua da Mooca, está a Fábrica de Tecidos Labor, construída a partir de 1910, desativada em 1987 e tombada pelo Condephaat e pelo Conpresp em 2014. O edifício, que já abrigou a casa noturna Fabbrica 5, atualmente está ocupado por moradores semteto brasileiros e estrangeiros ${ }^{72}$ (figura 7), explicitando a desigualdade na ocupação do território a despeito de constituir "uma permanência do perfil da Mooca de outrora" e resistir "aos processos de remodelação de um reduto fabril paulista"..$^{73}$

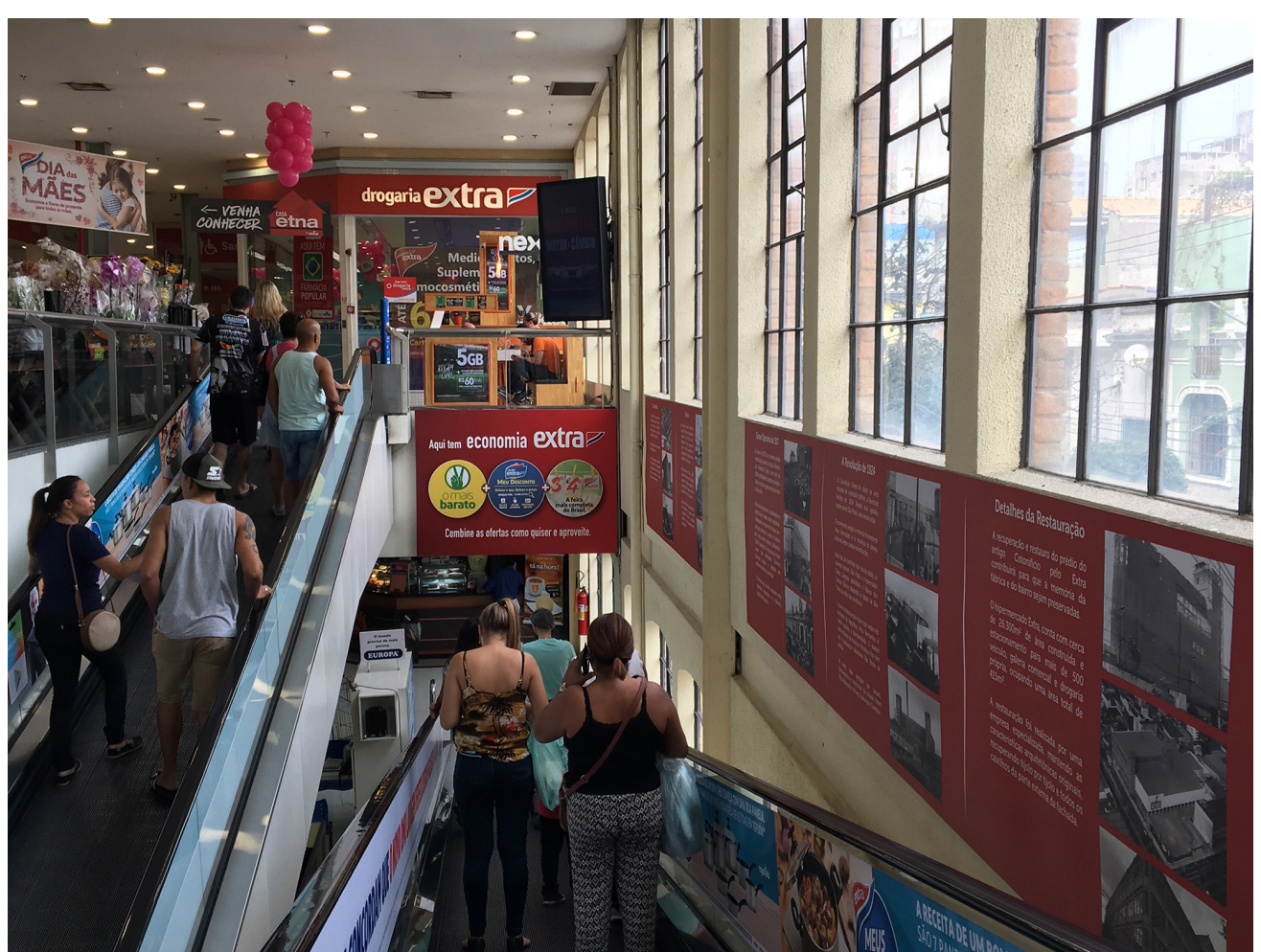

Figura 5 - Painel de fotos sobre a história do antigo Cotonifício Crespi, instalado junto às escadas rolantes no interior do supermercado, maio de 2019. Fotografia: Clarissa M. R. Gagliardi. 


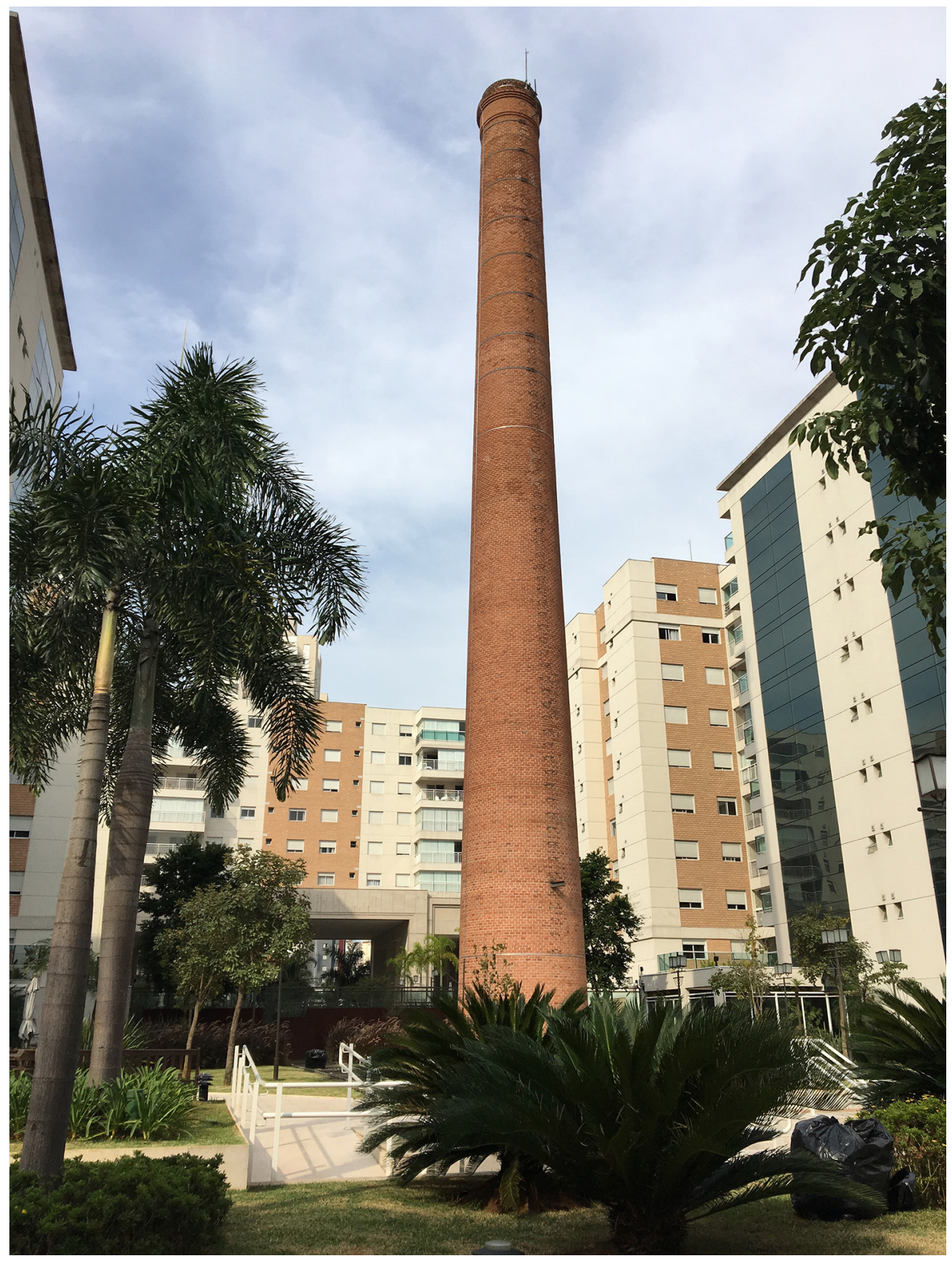

Figura 6 - Chaminé da antiga Fábrica União, maio de 2019. Fotografia: Clarissa M. R. Gagliardi. 
Figura 7 - Ocupação de sem-teto no interior da antiga Fábrica de Tecidos Labor, maio de 2019. Fotografia: Clarissa M. R. Gagliardi.
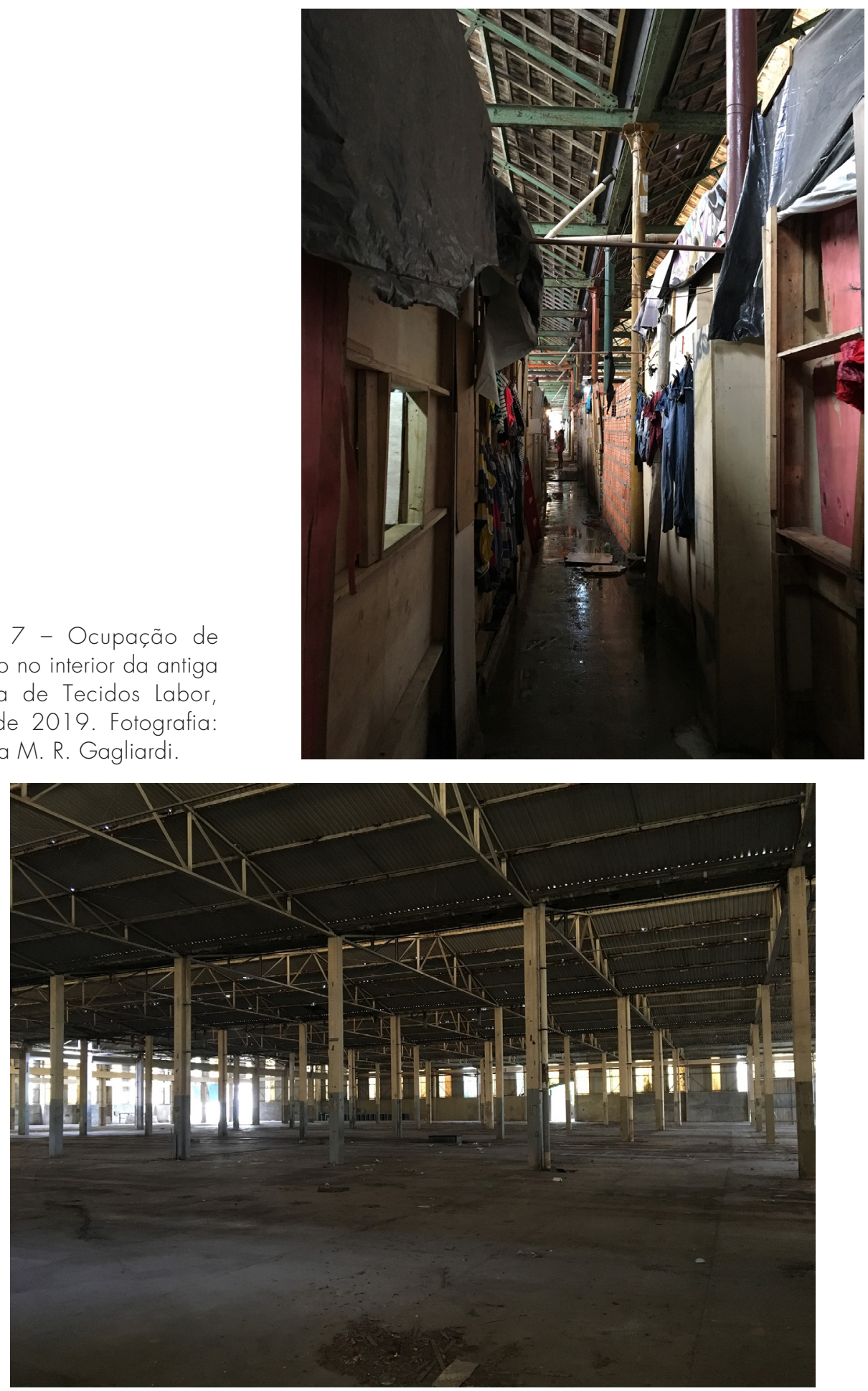

Figura 8 - Interior do galpão da antiga Fábrica Gazarra, nov. 2018. Fotografia: Clarissa M. R. Gagliardi. 
Enquanto a Mooca é modelar com relação à vantagem do mercado imobiliário na disputa pelos territórios fabris, nos distritos onde faltam infraestruturas que tornem tais terrenos mais atrativos, sobressaem outras formas de apropriação e reúso desse imobiliário. Único exemplar, dentre os indicados, sem tombamento em nenhuma esfera, a Fábrica Metalúrgica Gazarra (figura 8) iniciou suas atividades em 1950 no Tatuapé e em 1978 transferiu-se para Itaquera, onde funcionou até 1999. É exemplar de um tipo de conversão para uso social. Após - fechamento das portas, as instalações da fábrica ficaram abandonadas e, em 2013, foi desapropriada pela prefeitura para dar lugar a uma universidade pública, um novo campus da Unifesp. A luta dos movimentos sociais da zona leste pela criação de uma universidade remonta os anos 1980 e, além de indicar a área da antiga fábrica para sediar o novo campus, participaram ativamente da construção do projeto político pedagógico da unidade. ${ }^{74} \bigcirc$ fato dessa unidade da universidade abrigar iniciativas como o Observatório de Políticas Públicas da zona leste e o Instituto das Cidades é emblemático dessa conquista. Aqui é maior o peso da participação popular na destinação de uso desse imobiliário, ao mesmo tempo em que é menor a pressão das incorporadoras sobre os terrenos, visando destiná-los à população de maior poder aquisitivo. Dessa forma, embora a Amo a Mooca e os movimentos pela universidade na zona leste tenham objetivos semelhantes para o patrimônio cultural, os interesses dos seus oponentes atuam diversamente na sua destinação. A conquista pela Unifesp e as perspectivas que ela abre em termos de inclusão, geração de novas oportunidades de emprego, renda, participação social, qualificação profissional e do próprio território da zona leste constitui um contraponto importante frente ao avanço daqueles serviços precários que caracterizam o terciário em zonas periféricas.

\section{CONSIDERAÇÕES FINAIS}

Na revisão dos tombamentos feitos pelo IPHAN a partir dos anos 1980, embora se evidenciem esforços de superação da seletividade de sua preservação, assumindo-se para o patrimônio brasileiro diretrizes mais plurais como expressa a Constituição de 1988, não se verificam ações de reconhecimento e preservação de bens relativos à memória industrial como bairros operários ou paisagens marcadamente industriais. ${ }^{75}$ A presença tardia e morosa dos órgãos de tombamento na proteção desses bens, sem capacidade de preservar elementos que caracterizam o trabalho industrial como um todo, tem ação reativa pautada nas edificações e,
74. Cf. Arantes; Santos Junior (2017)

75. Cf. Marins (2016). 
em geral, em ícones e efeito "fachadista". Demolições, uso fetichista dos imóveis ou requalificação com perspectivas de atração de investimentos que privilegiam usos que não cumprem função social acabam sendo recorrentes. Em geral, os usos privilegiados na refuncionalização deste patrimônio, majoritariamente característicos do setor terciário da economia nos casos citados, não são capazes de rememorar o amplo sistema do trabalho industrial além da fábrica, incluindo formas de morar, se divertir e do saber-fazer operário. No caso das experiências europeias analisadas, a refuncionalização do patrimônio industrial mostra-se mais sensível à complexidade dos seus sistemas industriais originários, contemplando de modo mais amplo a dimensão sociocultural do território, ainda que possam estar associadas a negócios típicos da economia de serviços como o turismo e o lazer.

A organização de moradores para obter contrapartidas nos processos de intervenção no patrimônio, reconhecido como um valor cultural importante para a identidade, é mais presente nos distritos próximos do centro, cujos empreendimentos são mais voltados à população com maior poder aquisitivo e onde se observa uma correlação de forças desfavorável à sociedade civil pró presenvação diante do avanço do mercado imobiliário. Nos distritos mais periféricos, as conquistas dos movimentos sociais da zona leste são maiores, resultando num uso mais social do patrimônio.

Ao recuperar a função social do museu, evidenciada com a Nova Museologia, entende-se o patrimônio como lugar de formação. Não nos referimos apenas à educação não formal por meio da qual os museus, por exemplo, são acionados para qualificar alunos e professores como complemento das atividades escolares e formativas, mas especialmente às experiências de reativação do patrimônio que dão continuidade ao trabalho como prática viva que dá sentido aos espaços laborais. Por esse ângulo, é válido frisar os usos do patrimônio industrial edificado voltados à formação profissional, fazendo persistir a concepção do trabalho como valor, não como memória apenas, mas como perspectiva de inserção de novas gerações que em grande medida tiveram como suporte os recursos advindos de pais e avós operários. Assim, entende-se que o patrimônio fabril transformado em universidade, por exemplo, contempla de fato uma salvaguarda do trabalho quando atua na formação de novos profissionais, ao passo que outras tentativas que reinserem o patrimônio industrial no circuito do consumo, transformando-o em shoppings, casas noturnas ou ainda ativos imobiliários destinados ao investimento do capital urbano desterritorializado reforçam uma visão rentista do espaço urbano.

Preservar sinalizando a função social do patrimônio fabril, garantindo os valores que nele se consubstanciam, parece urgente em contextos de financeirização voraz do espaço urbano. 


\section{REFERÊNCIAS}

FONTES IMPRESSAS

DW BRASIL. Rota da Cultura Industrial Reconta passado da Região do Ruhr. Disponível em: $<$ https://bit.ly/3bq0cBv>. Acesso em: 15 set. 2019.

EXPANSÃO imobiliária na Zona Leste de São Paulo faz vila histórica desaparecer. Folha de S.Paulo, 4 set. 2019. Disponível em: <https://bit.ly/3dNtzPP>. Acesso em: 28 set. 2019.

IMÓVEL de antiga fábrica e balada na Mooca vira invasão sem-teto. Folba de S.Paulo, 13 set. 2018. Disponível em: <https://bit.ly/2zvWJ74>. Acesso em: 9 out. 2019

ROLNIK, Raquel. Casas demolidas na zona leste impediam a verticalização de São Paulo. Coluna Cidade para Todos. Jornal da USP, 5 set. 2019. Disponível em: <https://bit.ly/35WirND>. Acesso em 15 set. 2019.

FONTES ICONOGRÁFICAS

GAGLIARDI, Clarissa Maria. Chaminé da antiga Fábrica União. 2019a. 1. Fotografia.

GAGLIARDI, Clarissa Maria. Entrada do canteiro de obras da Faculdade das Américas. $2019 \mathrm{~b}$. 1. Fotografia.

GAGLIARDI, Clarissa Maria. Interior do galpão da antiga Fábrica Gazarra. 2018. 1. Fotografia.

GAGLIARDI, Clarissa Maria. Moinho Matarazzo. 2019c. 1. Fotografia.

GAGLIARDI, Clarissa Maria. Moinhos Minetti e Gamba. 2019d. 1. Fotografia.

GAGLIARDI, Clarissa Maria. Ocupação de sem-teto no interior da antiga Fábrica de Tecidos Labor. 2019e. 1. Fotografia. 
GAGLIARDI, Clarissa Maria. Painel de fotos sobre a história do antigo Cotonifício Crespi. $2019 \mathrm{f}$. 1. Fotografia.

LOURENÇÃO, Carolina Figueiredo. Fachada lateral do edifício do antigo Cotonifício Crespi. 2019. 1. Fotografia.

LIVROS, ARTIGOS E TESES

ANDRADE, Paula Rodrigues. O Patrimônio da Cidade: arquitetura e ambiente urbano nos inventários de São Paulo da década de 1970. 2012. 153 f. Dissertação (Mestrado) - Faculdade de Arquitetura e Urbanismo da Universidade de são Paulo - FAU-USP, São Paulo, 2012.

ARANTES, Antônio Augusto. Sobre inventários e outros instrumentos de salvaguarda do patrimônio cultural intangível: ensaio de antropologia pública. Anuário Antropológico 20072008, Rio de Janeiro, p.173-222, 2009.

ARANTES, Otília; VAINER, Carlos; MARICATO, Ermínia. A cidade do pensamento único: desmanchando consensos. Petrópolis, RJ: Vozes, 2000.

ARANTES, Pedro Fiori; SANTOS JUNIOR, Wilson Ribeiro dos. Instituto das Cidades: uma construção conjunta da UNIFESP e dos movimentos sociais da Zona Leste. In: ENCONTRO NACIONAL DA ASSOCIAÇÃO NACIONAL DE PÓS-GRADUAÇÃO E PESQUISA EM PLANEJAMENTO URBANO E REGIONAL, 17, São Paulo, Anais do XVII ENANPUR. São Paulo, 2017. p.1-19.

BAUDEMONT, Suzanne. A gentry, sua temporada e seus ritos. In: CHARLOT, Monica e MARX, Roland (orgs). Londres, 1851-1901: a era vitoriana ou o triunfo das desigualdades, Rio de Janeiro: Jorge Zahar, 1993. p. 76-84

BERGER, Stefan; WICKE, Christian. Um imaginário pós-industrial? A popularização do patrimônio industrial no Ruhr e a representação de sua identidade regional. Estudos Históricos, Rio de Janeiro, v. 27, n. 54, p. 231-254, 2014.

BOURDIEU, Pierre. Classes e classificações. In: BOURDIEU, Pierre. A distinção: crítica social do julgamento. São Paulo: Edusp; Porto Alegre: Zouk, 2008. p. 434-447.

BOURDIEU, Pierre. Sobre o poder simbólico. In: BOURDIEU, Pierre. O poder simbólico. Rio de Janeiro: Bertrand Brasil, 2009.

CANO, Wilson. A desindustrialização no Brasil. Economia e Sociedade. Campinas, v. 21, Número Especial, 2012. p. 831-851. 
CARLOS, Ana Fani Alessandri. Espaço-tempo na metrópole: a fragmentação da vida cotidiana. São Paulo: Contexto, 2001.

CARVAlHO, Mônica de. Cidade global: anotações críticas de um conceito. São Paulo em Perspectiva. Revista Fundação Seade. São Paulo, volume 14, n 4, out.dez, p. 70-82, 2000.

CARVALHO, Mônica de et al. Desindustrialização: consequências para o mercado de trabalho da Zona Leste. In: OLIVEIRA, Ana Cláudia de; JUNQUEIRA, Maria Aparecida; WANDERLEY, Mariangela Belfiore. (eds). Constelações Urbanas: territorialidades, fluxos, manifestações estético-políticas. São Paulo: Educ; Pipeq, 2018.

CASTELlS, Manuel. A Questão Urbana. São Paulo: Paz e Terra, 1983.

CASTRIOTA, Leonardo Barci. Patrimônio Cultural: conceitos, políticas, instrumentos. São Paulo: Annablume; Belo Horizonte: IEDS, 2009.

CHOAY, Françoise. A Alegoria do Patrimônio. São Paulo: Unesp, 2001.

DESVALLÉES, André; MAIRESSE, François (editores). Conceitos-chave de Museologia. Tradução e comentários de Bruno Brulon Soares e Marília Xavier Cury. São Paulo: Comitê Brasileiro do Conselho Internacional de Museus, Conselho Internacional de Museus - ICOM, Pinacoteca do Estado de São Paulo; Secretaria de Estado da Cultura, 2013.

FERREIRA, João Sette Whitaker. O mito da cidade-global: o papel da ideologia na produção do espaço urbano. Petropolis, RJ: Vozes; São Paulo: Unesp, 2007.

FIESP. Diretoria Regional do CIESP de São Paulo. Informações econômicas e da indústria de transformação. São Paulo, 2017.

FIX, Mariana. São Paulo cidade global: fundamentos financeiros de uma miragem. São Paulo: Boitempo, 2007.

FRÚGOLI JR., Heitor. Centralidade em São Paulo: trajetórias, conflitos e negociações na metrópole. São Paulo: Cortez Editora; Edusp, 2000.

GLAZER, Natan. A Renovação das Cidades. In: DAVIS, Kingsley. Cidades: a urbanização da bumanidade, Rio de Janeiro: Zahar Editores, 1972, p. 190-206.

GOTTDIENER, Mark. A Produção Social do Espaço Urbano. São Paulo: Edusp, 1993. 
GUERRA, Marília Falconi; VASCOLCELlOS, Camilo de Mello. Museologia e Turismo de Base Comunitária em Reservas Extrativistas: diálogos possíveis. Revista Iberoamericana de Turismo - RITUR, Penedo, v. 8, n. 4, p.96-114, 2018.

HALL, Peter. A cidade do empreendimento. In: Cidades do Amanhã: uma história intelectual do planejamento e do projeto urbanos no século XX. São Paulo: Perspectiva, 2011.

HARVEY, David. A condição pós-moderna. São Paulo: Loyola, 1994.

KÜHL, Beatriz Mugayar. Preservação do patrimônio arquitetônico da industrialização: problemas teóricos de restauro. Cotia, SP: Ateliê; São Paulo: Fapesp, 2009.

MARCHI, Polise Moreira. IBA Emscher Park: uma oficina de 10 anos para a reestruturação da antiga região industrial do Vale do Ruhr, Alemanha. In: ENCONTRO NACIONAL DA ASSOCIAÇÃO NACIONAL DE PÓS-GADUAÇÃO E PESQUISA EM PLANEJAMENTO URBANO E REGIONAL,11, Salvador, Anais do XI-ENANPUR, Salvador, UFBA, 2005. p. 1-19.

MARINS, Paulo César Garcez. Novos Patrimônios, um novo Brasil? Um balanço das políticas patrimoniais federais após a década de 1980. Estudos Históricos, Rio de Janeiro, v. 29, n. 57, p. 9-28, 2016.

MARQUES, Eduardo. De volta aos capitais para melhor entender a política urbana. Novos Estudos CEBRAP. São Paulo, v. 35, n. 2, p. 15-23, jul. 2016.

MENEGUELLO, Cristina. Patrimônio Industrial como tema de pesquisa. In: SEMINÁRIO INTERNACIONAL HISTÓRIA DO TEMPO PRESENTE, 1, Florianópolis, Anais do I Seminário Internacional História do Tempo Presente, UDESC, ANPUH-SC, 2011. p. 1819-1834.

MONTEIRO, Fagner Diego Spíndola; LIMA, João Policarpo Rodrigues. Desindustrialização regional no Brasil. Revista Nova Economia. Belo Horizonte, UFMG, v. 27, n. 2, p. 247-293, ago. 2017.

OREIRO, José Luis; FREIJÓ, Carmen A. Desindustrialização: conceituação, causas, efeitos e o caso brasileiro. Revista de Economia Política, v. 30, n. 2 (118), p. 209-232, abr.-jun. 2010.

PARENT, Michel. O Conceito de Herança Mundial. O Correio da UNESCO, p. 32-36, out. 1988.

POUlOT, Dominique. Museu e Museologia. Belo Horizonte: Autêntica, 2013. 
RODRIGUES, Angela Rosch. Estudo do Patrimônio Industrial com Uso Fabril da Cidade de São Paulo. 2011. X 245 f. Dissertação (Mestrado) - Faculdade de Arquitetura e Urbanismo da Universidade de São Paulo, São Paulo, 2011.

ROLNIK, Raquel. Guerra dos lugares: a colonização da terra e da moradia na era das finanças. São Paulo, Boitempo, 2015.

ROLNIK, Raquel; FRÚGOLI JUNIOR, Heitor. Reestruturação urbana da metrópole paulistana: a Zona Leste como território de rupturas e permanências. Cadernos Metrópole, São Paulo, n. 6, p.43-66, 2001.

RUBINO, Silvana. Enobrecimento Urbano. In: FORTUNA, Carlos; LEITE, Rogério Proença (orgs.). Plural de Cidades: novos léxicos urbanos. Coimbra: CES; Almedina, 2009, p. 25-40.

RUFINONI, Manoela Rossinetti. O registro e a documentação do patrimônio industrial no Brás e na Mooca. Revista CPC, São Paulo, n. 21 especial, p. 219-243, $1^{\circ}$ sem. 2016.

SANTANA, Danielle Cristina Dias de. Patrimônio, Paisagem e Território nos Planos Diretores: o Território de Interesse da Cultura e da paisagem no Plano Diretor Estratégico de São Paulo (2014). In: Encontro Nacional da Associação Nacional de Pós-Graduação e Pesquisa em Planejamento Urbano e Regional, 18, Natal, Anais do XVIII ENANPUR, Natal: UFRN, 2019. p. 1-22.

SANTOS, Milton. A natureza do espaço: técnica e tempo, razão e emoção. São Paulo: Edusp, 2009.

SASSEN, Saskia. As cidades na economia mundial. São Paulo: Studio Nobel, 1998.

SASSEN, Saskia. Expulsões: brutalidade e complexidade na economia global. São Paulo: Paz e Terra, 2016.

SMITH, Neil. A gentrificação generalizada: de uma anomalia local à "regeneração" urbana como estratégia urbana global. In: BIDOU-ZACHARIASEN, Catherine (coord). De Volta à Cidade: dos processos de gentrificação às políticas de "revitalização" dos centros urbanos. São Paulo: Annablume, 2006. p. 59-87.

SOARES, Bruno César Brulon. A Invenção do Ecomuseu: o caso do Écomusée du Creusot Montceau-les-Mines e a prática da museologia experimental. Mana, Rio de Janeiro, v. 21, n. 2, p. 267-295, 2015. 
ZANCHETI, Silvio Mendes. Conservação Urbana: textos de momento. Textos para discussão n. 30, Série Gestão da Conservação Urbana. Olinda: Centro de Estudos Avançados da Conservação Integrada, 2008, p. 1-23. Disponível em: <www.ceci-org>. Acesso em: 20 mar. 2011.

SITES

BASE DE DADOS sobre Bens Protegidos do CONDEPHAAT. Disponível em: <https://bit. ly/3fLLrfC>. Acesso em: 24 ago. 2019.

CIT - Cadastro de Imóveis Tombados do CONPRESP. [s. d.]. Disponível em: <www.prefeitura. sp.gov.br>. Acesso em: 24 ago. 2019.

CONDEPHAAT. Processo de tombamento da Antiga Fábrica de Tecidos Labor. [s. d.]. Disponível em: <https://bit.ly/2YYr7Sc>. Acesso em: 28 set. 2019.

CONPRESP. Ata da $667^{\mathrm{a}}$ Reunião Ordinária do Conpresp. Disponível em: <https://bit. ly/2WRgBJP>. Acesso em: 24 ago. 2019.

CONPRESP. Ata da $679^{a}$ Reunião Ordinária do Conpresp. Disponível em: <https://bit. ly/2zCnSoJ>. Acesso em: 24 ago. 2019.

CONPRESP. Resolução No 06/CONPRESP/2016. Disponível em: <https://bit.ly/3cvFwJo>. Acesso em: 24 fev. 2020.

CONPRESP. Resolução No 07/CONPRESP/2008. Disponível em: <https://bit.ly/2Z0TJdI>. Acesso em: 9 out. 2019

DPH - Departamento de Patrimônio Histórico de São Paulo. [s. d.]. Disponível em: <https:// bit.ly/2T3OB4z>. Acesso em: 10 mar. 2018.

ÉCOMUSÉE-CREUSOT-MONTCEAU. Disponível em: <https://bit.ly/3dE7xPl>. Acesso em: 15 set. 2019.

IBGE. Instituto Brasileiro de Geografia e Estatística, Pesquisa Industrial Mensal-dez. 2019. Disponível em: <https://bit.ly/35T8Mrg>. Acesso em: 5 fev. 2020.

ICOMOS - TICCIH Princípios conjuntos para a Conservac?a?o de Si?tios, Estruturas, A?reas e Paisagens de Patrimônio Industrial. "Os Princípios de Dublin”, 2011. Disponível em: <https:// bit.ly/2WszYtF>. Acesso em: 24 fev. 2020. 
IRONBRIDGE GORGE MUSEUMS. Disponível em: <https://www.ironbridge.org.uk>. Acesso em: 15 set. 2019.

MUSEOTORINO. Recupero Del Lingotto. Disponível em: <https://bit.ly/3fH18oi >. Acesso em: 15 set. 2019.

PREFEITURA DO MUNICÍPIO DE SÃO PAULO. Programa Patrimônio e Referências Culturais nas Subprefeituras. Secretaria Municipal de Cultura e Departamento do Patrimônio Histórico. Disponível em: <https://bit.ly/2ySKPnO>. Acesso em: 24 ago. 2019

PREFEITURA DO MUNICÍPIO DE SÃO PAULO. Plano Diretor Estratégico 2014. Disponível em: <https://bit.ly/3cvojA3>. Acesso em: 9 out. 2019.

Sistema de Consulta do Mapa Digital da Cidade de São Paulo. Disponível em <http://geosampa. prefeitura.sp.gov.br/PaginasPublicas/_SBC.aspx\#>. Acesso em: 02 ago. 2020

TICCIH. Carta Niznby Tagil sobre o Patrimônio Industrial, 2003. Disponível em: https://bit. ly/2YW8KgR. Acesso em: 26 fev. 2018

Artigo apresentado em 10/12/2019. Aprovado em 25/03/2020.

\section{(cc) BY}

All the contents of this journal, except where otherwise noted, is licensed under a Creative Commons Attribution License 